\title{
Articles
}

\section{Not the Same Old Story: Using Narrative Theory to Understand and Overcome the Plausibility Pleading Standard}

\author{
Anne E. Ralph*
}

\section{INTRODUCTION}

The Twombly 1 and Iqbal 2 cases drastically changed the pleading standard for lawsuits governed by the Federal Rules of Civil Procedure, requiring a litigant to plead facts demonstrating that her right to relief goes beyond "sheer possibility" and is, in fact, "plausible." 3 Prior to these cases, litigants and judges alike understood that Rule 8, which by its terms requires only a "short and plain

\footnotetext{
* Assistant Clinical Professor, The Ohio State University Michael E. Moritz College of Law. I wish to thank LexisNexis and the joint LWI/ALWD Scholarship Grant Committee for the generous grant that supported this work. I am grateful to the following individuals for helpful discussion and comments: Mary Beth Beazley; Christopher M. Fairman; Elizabeth Fajans; Ian Gallacher; Arthur F. Greenbaum; J. Christopher Rideout; Robin Wellford Slocum; and Monte Smith. I also received useful reactions to this project from participants in the Fourth Biennial Applied Legal Storytelling Conference (July 2013), the Southeast Regional Legal Writing Conference (April 2013), and the ALWD Scholars' Forum at the Empire State Legal Writing Conference (June 2012). Finally, I thank my research assistants Justin Joyce and Sara Salari for their excellent work. This article is dedicated to my mother, Susan M. Ralph, with gratitude and admiration.

1. Bell Atl. Corp. v. Twombly, 550 U.S. 544 (2007).

2. Ashcroft v. Iqbal, 556 U.S. 662 (2009).

3. Id. at 678. Although the Court in Twombly and Iqbal used various terms to describe what it was requiring of a complaint, it is the word "plausible" to which those who would characterize the decisions continually return. See, e.g., Edward Brunet, The Substantive Origins of "Plausible Pleadings": An Introduction to the Symposium on Ashcroft v. Iqbal, 14 LEWIS \& CLARK L. REV. 1, 2 (2010) ("[T]he word plausible, as used and perhaps overused in Justice Kennedy's Iqbal opinion twenty-two times, sets forth this new standard.").
} 
statement of the claim," 4 embodied a liberal notice pleading standard.5 Post-Twombly and Iqbal, a court must carefully weigh the allegations in a pleading to determine whether the allegations state a legal claim that is plausible; the plausibility inquiry requires the reviewing court to consider "obvious alternative explanation[s]" and "to draw on its judicial experience and common sense."6

The plausibility standard has been widely denounced as a frustration for plaintiffs, a slippery and idiosyncratic standard, and a barrier to justice.7 These criticisms have particular import for civil rights and discrimination plaintiffs, who stand to be affected uniquely by the plausibility standard.

However, pleading post-Twombly and Iqbal need not be the tale of woe that so many scholars foresee. In fact, as this Article argues, greater awareness of narrative theory and greater reliance on narrative techniques can help litigants and judges understand and comply with the plausibility standard.

Because the Twombly and Iqbal plausibility standard requires a litigant to persuade the court that her claim has facial plausibilitythat is, does the description of the way events occurred "ring true"? the standard is especially appropriate for application of narrative techniques. This Article argues that the Supreme Court has implicitly directed lower courts to evaluate pleadings for the strength of the stories they tell, inviting litigants to use storytelling techniques to endow pleadings with narrative richness. As a result, the puzzle created by the plausibility pleading standard can be solved by using storytelling techniques.

Section I of this Article gives an account of the genesis of the Twombly/lqbal plausibility pleading standard, noting how it emerged and has evolved in the Supreme Court's recent jurisprudence. Section Il explores some of the most common criticisms of the Twombly and Iqbal decisions and the plausibility standard, including criticisms that the standard requires factual information that is beyond the reach of many plaintiffs, and that it confers excessive discretion upon trial court judges. Section III gives an overview of narrative theory and narrative techniques in light of their usefulness in interpreting the plausibility standard. Section IV demonstrates how greater reliance

4. FED. R. CIV. P. 8(a)(2).

5. See, e.g., Christopher M. Fairman, Heightened Pleading, 81 TEx. L. REv. 551, 554 (2002) [hereinafter Fairman, Heightened Pleading]; Benjamin Spencer, Plausibility Pleading, 49 B.C. L. REv. 431, 434-39 (2008) [hereinafter Spencer, Plausibility Pleading].

6. Iqbal, 556 U.S. at 679,682 .

7. See infra notes 82-143 and accompanying text.

8. See infra notes 104 and 190 and accompanying text. 
on narrative helps resolve the plausibility pleading puzzle, because it provides litigants and judges with a useful guide in giving meaning to the plausibility standard. Section IV also addresses problems that may arise from an increased emphasis on narrative. Finally, the Article offers suggestions for litigants and courts to proceed with greater emphasis on narrative.

\section{LEGAL BACKGROUND: THE RISE OF PLAUSIBILITY PLEADING}

\section{A. Pre-Plausibility: The 1938 Rules and Conley's "No Set of Facts" Formulation}

Prior to the Supreme Court's decisions in Twombly and Iqbal, the familiar language of Rule 8 , which requires only that a pleading contain "a short and plain statement of the claim showing that the pleader is entitled to relief," 9 was understood to embody a liberal notice pleading standard. 10

Rule 8, promulgated as part of the 1938 Federal Rules of Civil Procedure, was intended to simplify the preexisting pleading landscape, which largely relied on "fact pleading": the fact-pleading regime "overemphasized hypertechnical distinctions," "produced conflicting judicial interpretations," and created a "quagmire of unresolvable disputes" about whether facts had been properly pleaded.11 For instance, prior to the 1938 Rules, many states implemented supposed procedural reforms known as the Field Code; under the code, pleading rules provoked "unresolvable disputes" about whether allegations in a pleading should be characterized as assertions of "ultimate fact," as "mere evidence" or as "conclusions"all of which were virtually undistinguishable from one another.12 Such disputes wasted court and litigant time, and often gave artful pleaders

\section{FED. R. CIV. P. 8(a)(2).}

10. See, e.g., Fairman, Heightened Pleading, supra note 5, at 554 (explaining how Rule 8 , "with its splendid simplicity, stands as the centerpiece of a procedural system designed to rectify the pleading abuses of the past"); see also, e.g., Spencer, Plausibility Pleading, supra note 5, at 434-39 (tracing the history of Rule 8 notice pleading). It must be noted that, despite the familiar language of Rule 8, there have long been areas of the law that, ostensibly governed by the liberal language of Rule 8, were in fact "riddled with requirements of particularized fact-based pleading," as my colleague Christopher M. Fairman has argued and carefully catalogued. Christopher M. Fairman, The Myth of Notice Pleading, 45 ARIZ. L. REV. 987, 988 (2003) [hereinafter Fairman, Notice Pleading] (discussing substantive areas of the law in which courts imposed heightened pleading standards including antitrust, civil rights, RICO, conspiracy, and defamation claims). Civil rights claims are among those cases in which courts sometimes imposed a heightened pleading standard, even though Conley directed otherwise. See id. at 1027-32.

11. Fairman, Heightened Pleading, supra note 5, at 555-56.

12. Richard L. Marcus, The Revival of Fact Pleading Under the Federal Rules of Civil Procedure, 86 COLUM. L. REV. 433, 438 (1986). 
a tactical advantage, unrelated to the merits of a case, at the expense of "the unwary or the inexperienced pleader."13 Written to eliminate such protracted and wasteful disputes, the 1938 Rules, and Rule 8 in particular, were intended by their drafters to be "simple, uniform, and transsubstantive."14

Under Rule 8, as instituted in the 1938 Rules, pleadings were intended only to provide notice-not to state facts, narrow issues for discovery, or dispose of nonmeritorious claims.15 As a whole, the 1938 Rules were designed to guarantee access to courts, guarantee litigants their day in court, and enable determinations on the merits. 16

This understanding of Rule 8's liberal notice pleading standard was encouraged by the Supreme Court's own language in Conley v. Gibson. In Conley, the Court memorably explained that, under Rule 8, "a complaint should not be dismissed for failure to state a claim unless it appears beyond doubt that the plaintiff can prove no set of facts in support of his claim which would entitle him to relief." 17 In Conley, a group of African-American railway workers alleged that their union had violated its duty of fair representation.18 The union moved to dismiss the complaint on the ground that the plaintiffs did not set forth specific facts in support of their discrimination claim.19

The Supreme Court held that the Conley plaintiffs had stated a claim under Rule 8, and pronounced that "a complaint should not be dismissed for failure to state a claim unless it appears beyond doubt that the plaintiff can prove no set of facts in support of his claim which would entitle him to relief." 20 According to the Court in Conley, the "no set of facts" formulation was "the accepted rule" for assessing the sufficiency of a complaint.21 Because the allegations in plaintiffs' complaint, if proven, would have demonstrated a breach of the union's duty, the complaint was sufficient to survive a motion to dismiss.22

In addressing the defendants' argument that the plaintiffs' complaint "failed to set forth specific facts to support its general

13. 5 Charles Alan Wright \& Arthur R. Miller, Federal Practice and Procedure $§ 1218$ (3d ed. 2013).

14. Fairman, Heightened Pleading, supra note 5, at 556.

15. Id.

16. Id. at 558 .

17. Conley v. Gibson, 355 U.S. 41, 45-46 (1957) (emphasis added), abrogated by Bell Atl. Corp. v. Twombly, 550 U.S. 544 (2007).

18. Id. at 42 .

19. Id at 43,47 .

20. Id. at 45-46.

21. Id. at 46.

22. Id. 
allegations of discrimination," the Conley Court emphasized that "the Federal Rules of Civil Procedure do not require a claimant to set out in detail the facts upon which he bases his claim." 23 Importantly, the Court described pleading under the Federal Rules as "simplified 'notice pleading."'24

In Conley, the Supreme Court gave its imprimatur to the liberal pleading philosophy espoused in the Federal Rules, and effectively quieted any resistance to the rules. 25 Following Conley, the generally accepted view of pleading was that a pleading should survive a motion to dismiss for failure to state a claim as long as the allegations in the complaint demonstrated that plaintiff could possibly prove her entitlement to relief.26

\section{B. Twombly: The Death Knell for "No Set of Facts"}

Into this world of "no set of facts" notice pleading came Twombly, which sounded the death knell for notice pleading.27 In Twombly, the Court considered the proper standard for pleading an antitrust conspiracy under Section 1 of the Sherman Act through allegation of parallel conduct.28 The plaintiffs, a class of subscribers of local telephone and high speed internet services, alleged that the defendants, a group of incumbent local exchange carriers, violated Section 1.29

Under Section 1 of the Sherman Act, which forbids restraints of trade that are accomplished through contract, combination, or conspiracy, a pattern of parallel behavior is circumstantial evidence of an agreement to restrain trade, and is consistent with allegations of a conspiracy, but alone is not sufficient to establish a violation of

\footnotetext{
23. Id. at 47 .

24. Id.

25. Marcus, supra note 12 , at 433-34.

26. The understanding that Rule 8 embodied the liberal notice pleading standard highlighted in Conley was further supported by the Court's decisions in Leatherman and Swierkewicz. In Leatherman, the Supreme Court held that the Fifth Circuit could not impose "a more demanding rule for pleading a complaint under $\$ 1983$ than for pleading other kinds of claims for relief," affirming that it was inconsistent with both Rule 8 and Conley to require Section 1983 claims to be pleaded with more particularity than other claims governed by Rule 8 . Leatherman v. Tarrant Cnty. Narcotics Intelligence \& Coordination Unit, 507 U.S. 163, 167 (1993). In Swierkewicz, the Court held that it was error for the Second Circuit to require an employment discrimination complaint to contain specific facts establishing a prima facie case of discrimination in order to state a claim. Swierkiewicz v. Sorema N.A., 534 U.S. 506, 515 (2002). See also, e.g., Fairman, Notice Pleading, supra note 10, at 994-97 (tracing Supreme Court's repeated "embrace" of "simplified notice pleading" in Conley, Leatherman and Swierkewicz).

27. See, e.g., Spencer, Plausibility Pleading, supra note 5, at 431 ("Notice pleading is dead. Say hello to plausibility pleading.").

28. 550 U.S. at 553.

29. Id. at 549-51.
} 
Section 1.30 As the Court explained, "mere interdependent parallelism does not establish the contract, combination or conspiracy required by Sherman Act $\S 1$." 31 To establish a Sherman Act offense, a contract, combination or conspiracy must be demonstrated, in order to rule out the possibility that the defendants were merely acting independently. 32

The Twombly plaintiffs alleged parallel anticompetitive behavior by the defendants.33 Thus, they also needed to establish a contract, combination or conspiracy, and they attempted to include such allegations in the complaint. The allegation termed the "ultimate" allegation by the Supreme Court was this: "Plaintiffs allege ... that [the ILECs] have entered into a contract, combination or conspiracy to prevent competitive entry in their respective local telephone and/or high speed internet services markets and have agreed not to compete with one another and otherwise allocated customers and markets to one another." 34

Although plaintiffs had filed a complaint of 96 numbered paragraphs, spanning 28 pages, the Supreme Court ruled that the complaint's allegations were insufficient to survive a motion to dismiss. 35 In so holding, the Court announced a new definition of the standard a plaintiff must meet to survive a motion to dismiss for failure to state a claim under Section 1 of the Sherman Act: "stating such a claim requires a complaint with enough factual matter (taken as true) to suggest that an agreement was made." 36 Put another way, the Court required "plausible grounds to infer an agreement." 37 Allegations that "plausibly suggest[]" agreement would be "not merely consistent with" agreement, but rather would "raise[] a suggestion of... agreement." 38 The Court explained that the need to show plausible grounds to infer an agreement reflected Rule 8's "threshold requirement" that even a "plain statement' possess enough heft to 'sho[w] that the pleader is entitled to relief."' 39

As to the plaintiffs' complaint itself, the Court found the allegations insufficient under Rule 8 to state a claim that was plausible on its

30. Id. at 553 .

31. Id. at 553-54 (internal citation and quotation omitted).

32. Id. at 554 .

33. Id. at 548 .

34. Id. at $\mathbf{5 5 1}$ (quoting $\mathbf{5 1}$ of plaintiffs' Consolidated Amended Class Action Complaint).

35. Id. at 554 .

36. Id. at $\mathbf{5 5 6 .}$

37. Id.

38. Id. at 556-57.

39. Id. at 557 . 
face.40 Because the claim rested on descriptions of parallel conduct, the Court looked for any allegations in the complaint that would invest the ILECs' action "with a plausible suggestion of conspiracy." 41 However, the Court found that the ILECs' behavior was "natural" and "was not suggestive of conspiracy, not if history teaches anything." 42 In finding the plaintiffs' allegations of conspiracy implausible, the Court looked to an "obvious alternative explanation" for the ILECs' behavior, and found such an explanation in economic literature and history. 43 The Court explicitly relied on "prior rulings and considered views of leading commentators" as it concluded that another alternative better explained defendants' conduct, rendering plaintiffs' claim implausible. 44

In announcing the new plausibility standard, the Court emphasized that it did not require a claim be shown to be probable at the pleading stage: "Asking for plausible grounds to infer an agreement does not impose a probability requirement at the pleading stage; it simply calls for enough fact to raise a reasonable expectation that discovery will reveal evidence of illegal agreement." 45

The Court also put the Conley "no set of facts" formulation to rest, explaining that the "no set of facts" language should not be "read in isolation as saying that any statement revealing the theory of the claim will suffice unless its factual impossibility can be shown from the face of the pleadings." 46 Noting that the "no set of facts" formulation from Conley had "been questioned, criticized, and explained away long enough," the Court concluded it was "best forgotten as an incomplete, negative gloss on an accepted pleading standard." 47 The Court also explained that its ruling had "practical

40. Id. at 554 .

41. Id. at 566 .

42. Id. at 566-67.

43. Id. at 567 .

44. Id. at $556 \&$ n. 4 .

45. Id. at 556. The Court also noted that "a well-pleaded complaint may proceed even if it strikes a savvy judge that actual proof of those facts is improbable and that a recovery is very remote and unlikely." Id. (internal quotations and citations omitted).

46. Id. at 561. According to the Court, reading Conley literally would mean that "a wholly conclusory statement of claim would survive a motion to dismiss whenever the pleadings left open the possibility that a plaintiff might later establish some set of undisclosed facts to support recovery." Id. at 561 (internal quotations omitted). The Court also noted that "a good many judges have balked at ... the literal terms of the Conley passage." Id. at 562.

47. Id. at 562-63. As described infra Section II, the Court's rejection of the Conley standard jeopardizes the clarity and transsubstantivity intended by the drafters of the Federal Rules, places an unnecessarily heavy burden on plaintiffs, and threatens to reduce access to justice generally. Contrary to the majority's rejection of Conley's time-honored formulation, Justice Stevens' dissent provides a stirring defense of the Conley standard, explaining that the pleading standard in the Federal Rules as interpreted in Conley "does not require, or even invite, the pleading of facts." Id. at 580 (Stevens, J., dissenting). 
significance," in that it would not allow a plaintiff with a "mere possibility" of success to go forward with a "largely groundless claim" and force the expenses of discovery on a defendant faced with a meritless suit. 48

Following the Twombly decision, the contours of the plausibility pleading standard and the breadth of its applicability remained in question. 49 Would the standard apply only to antitrust cases that promised expensive discovery? Or was a more comprehensive change to civil pleading standards taking place? The Iqbal decision answered those questions.

\section{Iqbal: The Other Shoe Drops}

The Supreme Court's decision in Iqbal confirmed that the Twombly plausibility standard was indeed applicable to all cases governed by Rule 8 and further explicated that standard. 50

Following the attacks of September 11, 2001, Javaid Iqbal, a citizen of Pakistan and a Muslim, was arrested on criminal charges and detained by federal officials as a person "of high interest." 51 Iqbal filed a Bivens action against a number of federal officials, including the petitioners before the Supreme Court: John Ashcroft, former Attorney General of the United States, and Robert Mueller, who at the time of the case was the Director of the Federal Bureau of Investigation.52 Iqbal alleged that petitioners Ashcroft and Mueller had adopted an unconstitutional policy that subjected him to imprisonment on account of his race, religion or national origin. 53

The Court held that Iqbal's pleadings were insufficient to state a claim, because Iqbal had not pleaded sufficient "factual matter that, if taken as true, state[d] a claim that petitioners deprived him of his ... constitutional rights"; in other words, he failed the plausibility

48. Id. at 557-58. The Court specifically mentioned that discovery in antitrust cases "can be expensive." Id. at 559. The Court described the "potential expense" of discovery in the Twombly case as "obvious." Id. Noting that lower courts had had only "modest" success in "checking" the cost of discovery through careful supervision, the Court explained that requiring allegations to make out a plausible claim was the only hope for avoiding "the potentially enormous expense of discovery in cases with no reasonably founded hope that the discovery process will reveal relevant evidence." Id. at 559.

49. See, e.g., Scott Dodson, Pleading Standards After Bell Atlantic Corp. v. Twombly, 93 VA. L. REV. IN $\quad$ BRIEF $135, \quad 138 \quad$ (2007), http://www.virginialawreview.org/inbrief/2007/07/09/dodson.pdf ("What does Bell Atlantic really mean? ... [T] he Court's opinion presages more expansive application.").

50. Ashcroft v. Iqbal, 556 U.S. 662 (2009).

51. Id. at 666 .

52. Id.

53. Id. 
standard. 54

Although Iqbal's complaint described in detail the conditions under which he was held in a maximum security detention center, and although it detailed some of his claims against other defendants who were not before the Court, 55 the Court confined its review of the allegations in plaintiff's complaint to those explicitly concerning Ashcroft and Mueller.56

The Court ruled that Iqbal had failed to state a claim as to Ashcroft and Mueller, and, in so doing, further explained the plausibility standard: "A claim has facial plausibility when the plaintiff pleads factual content that allows the court to draw the reasonable inference that the defendant is liable for the misconduct alleged." 57 The Court explained that the plausibility standard requires a plaintiff to go beyond conclusory, legalistic allegations, 58 and also acknowledged that the standard requires something short of a demonstration that a claim is likely. 59

The Court established a two-step process for lower courts to use in determining whether the plausibility standard is met: First, the court should disregard any allegation in a pleading that is no more than a "legal conclusion" masquerading as a factual statement; "[ $t$ ]hreadbare recitals of the elements of a cause of action, supported by mere conclusory statements" should not be considered under the plausibility standard.60 The Court clarified that the first step is not the place for disregarding allegations that are "unrealistic or nonsensical"-allegations should be disregarded if they are "conclusory," not because they are "extravagantly fanciful."61

Second, the court should review the "well-pleaded factual allegations," assuming their truth, and "determine whether they plausibly give rise to an entitlement to relief." 62 This second step ensures that "only a complaint that states a plausible claim for relief

54. Id.

55. Those defendants allegedly "kicked him in the stomach, punched him in the face, and dragged him." Id. at 668 (quoting श 113 of Plaintiff's First Amended Complaint).

56. Id. at 668 .

57. Id. at 678 .

58. Id. (noting that the plausibility standard "demands more than an unadorned, thedefendant-unlawfully-harmed-me accusation").

59. Id. ('The plausibility standard is not akin to a 'probability requirement,' but it asks for more than a sheer possibility that a defendant has acted unlawfully.").

60. Id. at 679. The Court explained its departure from the broad language of Conley by stating that "Rule 8 ... does not unlock the doors of discovery for a plaintiff armed with nothing more than conclusions." Id.

61. Id. at 681 .

62. Id. at 679 . 
survives a motion to dismiss." 63 At this second step, the Court directed that a lower court should "draw on its judicial experience and common sense" to assess the plausibility of the pleader's claim.64 The Court termed the application of judicial experience and common sense "a context-specific task." 65

In Iqbal's case, the Court held that the complaint failed to plead sufficient facts to state a claim for unlawful and intentional discrimination at the hands of Mueller and Ashcroft.66 At the first plausibility step, the Court ignored, as conclusory "bare assertions," the allegations that Ashcroft and Mueller "knew of, condoned, and willfully and maliciously agreed to subject" Iqbal to confinement "as a matter of policy, solely on account of [his] religion, race, and/or national origin." 67 The Court also disregarded, as conclusory, the allegations that Ashcroft was the "principal architect" of the policy and that Mueller was "instrumental in adopting it." 68

At the second step, the Court concluded that the remaining factual allegations did not give rise to a plausible inference that Iqbal's arrest and detention were the result of intentional discrimination.69 According to the Court, there were "more likely explanations" for Iqbal's arrest and detention, which prevented his allegations from "plausibly establishing" his claim.70 On the facts that Iqbal alleged, the Court identified an "obvious alternative explanation": that the policy was legitimate, that the arrests were lawful and justified by a nondiscriminatory intent; given that alternative explanation, the Court found that "discrimination [was] not a plausible conclusion."71

Thus, with the lqbal decision, the plausibility pleading standard was extended to all cases governed by Rule 8 of the Federal Rules of Civil Procedure. As well, the Court gave lower court judges explicit permission to apply their "judicial experience and common sense" in assessing the plausibility of a pleader's entitlement to relief.72

\section{Post-Twombly and Iqbal}

The Supreme Court has not yet issued another foundational decision explaining the plausibility standard. Certainly, in the few

63. Id.

64. Id. at 679.

65. Id.

66. Id. at 680-84.

67. Id. at 680-81.

68. Id. at 680-81.

69. Id. at 681 .

70. Id. at 682.

71. Id.

72. Id at 679 . 
years following Twombly and Iqbal, the Supreme Court has not disavowed the cases; thus, the plausibility pleading standard remains a puzzle for litigants and lower courts to study and understand.73

Lower courts have admitted the plausibility standard does not come with much guidance, and have struggled to apply it.74 Perhaps most significantly for this Article, the Seventh Circuit described the plausibility standard as a directive from the Supreme Court ruling "that the plaintiff must give enough details about the subject-matter of the case to present a story that holds together." 75 However, many lower court characterizations of plausibility have been less helpful; among other things, courts have wrestled with the definition of "plausibility" 76 and with the question of how judicial experience and common sense should be used in evaluating a complaint.77 Courts

73. Recent decisions from the Supreme Court demonstrate the continued applicability of the plausibility standard, including Skinner v. Switzer, 131 S. Ct. 1289, 1296, 179 L. Ed. 2d 233 (2011) and Matrixx Initiatives, Inc. v. Siracusano, 131 S. Ct. 1309, 1313 (2011).

In Skinner, a state prisoner filed an action under 42 U.S.C. $\$ 1983$ claiming that Texas violated his right to due process by refusing to allow him access to material for DNA testing. Skinner, $131 \mathrm{~S}$. Ct. at 1295 . The Skinner decision was notable because it gave a nod to the plausibility standard, but in doing so relied on a pre-Twombly and Iqbal formulation of the standard for a motion to dismiss for failure to state a claim. Id. at 1296. Neither Justice Ginsburg's majority opinion nor Justice Thomas's dissent mentioned Twombly or lqbal by name. Instead, the majority opinion relied on Swierkewicz v. Sorema, N.A., id. (citing Swierkiewicz v. Sorema N.A., 534 U.S. 506, 514 (2002)), a 2002 case which established that, in order to survive a motion to dismiss, a discrimination plaintiff need not plead facts alleging a prima facie case, but rather need only include "'a short and plain statement of the claim showing that the pleader is entitled to relief ... 'giv[ing] the defendant fair notice of what the plaintiff's claim is and the grounds upon which it rests." Swierkiewicz, 534 U.S. at 512 (citing FED. R. CIV. P. 8(a) and Conley, 355 U.S. at 47). To the extent Swierkewicz embodied the spirit of a "simplified pleading standard" applicable to all civil actions, id. at 513 , the Court's decision to cite that case may signify that simplified notice pleading retains some viability. See also John M. Barkett, Skinner, Matrixx, Souter, and Posner: Twombly and Iqbal Revisited, 12 SEDONA CONF. J. 69, 78 (2011). Cf. Joseph A. Seiner, After Iqbal, 45 WAKE FOREST L. REV. 179, 193 (2010) [hereinafter Seiner, After Iqbal] ("It is worth considering that there may be serious concern following Iqbal as to the validity of the Swierkiewicz decision."); Adam N. Steinman, The Pleading Problem, 62 STAN. L. REv. 1293, 1310 (2010) ("The continued vitality of ... Swierkiewicz is in doubt.").

In Matrixx Initiatives, Inc. v. Siracusano, 131 S. Ct 1309, 1313 (2011), plaintiffs brought a claim for securities fraud under $\S 10(\mathrm{~b})$ of the Securities Exchange Act of 1934, 48 Stat. 891, as amended, 15 U.S.C. $\$ 78 \mathrm{j}(\mathrm{b})$, and Securities and Exchange Commission (SEC) Rule 10b-5, 17 CFR $\S 240.10 \mathrm{~b}-5$ (2010). Citing Twombly and lqbal, the Supreme Court held that plaintiffs had stated a claim, because the complaint's allegations of materiality sufficed "to 'raise a reasonable expectation that discovery will reveal evidence' satisfying the materiality requirement ... and to 'allo[w] the court to draw the reasonable inference that the defendant is liable for the misconduct alleged."' Id. at 1323.

74. See Alex Reinert, Pleading as Information-Forcing, 75 LAW \& CONTEMP. ProBs. 1, 8 (2012) [hereinafter Reinert, Pleading as Information-Forcing] ("Courts have struggled to comprehend the outer limits of plausibility and the role of their own experience when adjudicating a motion that historically has not involved determinations of fact.").

75. Swanson v. Citibank, N.A., 614 F.3d 400, 404 (7th Cir. 2010).

76. Reinert, Pleading as Information Forcing, supra note 74 , at 16 \& nn. 100-01 (collecting cases).

77. Id. at $17 \&$ n. 105-07 (collecting cases). 
have variously described the plausibility standard as "confusing,"78 "opaque,"79 "relative," 80 and "malleable." 81 The following section of this Article will describe in further detail the main criticisms of the plausibility pleading standard that have emerged since its announcement.

\section{CRITICISMS OF PLAUSIBILITY PLEADING}

Academic reactions to the newly minted plausibility standard have been highly, if not entirely, negative.82 The Twombly and Iqbal decisions have been called, among other things, "a more demanding standard that requires a greater factual foundation than previously was required or originally intended"83; "an embarrassment to the American Judicial System in which a majority of the Supreme Court chose to reject the rule of law" 84 ; and "a new and ultimately ill-advised direction" for pleading in civil suits. 85

Commentators ascribe various underlying motivations to these decisions. ${ }^{86}$ Some theorize that the Court simply could not accept that

78. Phillips v. Cnty. of Allegheny, 515 F.3d 224, 230 (3d Cir. 2008) ("What makes Twombly's impact on the Rule 12(b)(6) standard initially so confusing is that it introduces a new 'plausibility' paradigm for evaluating the sufficiency of complaints. At the same time, however, the Supreme Court never said that it intended a drastic change in the law.").

79. Swanson, 614 F.3d at 411 (Posner, J., dissenting) (describing Iqbal's general requirement of "plausibility" as having been established in "opaque language").

80. Cooney v. Rossiter, 583 F.3d 967, 971 (7th Cir. 2009) ("In other words, the height of the pleading requirement is relative to circumstances. We have noted the circumstances (complexity and immunity) that raised the bar in the two Supreme Court cases.").

81. Courie v. Alcoa Wheel \& Forged Prods., 577 F.3d 625, 630 (6th Cir. 2009) ("Exactly how implausible is 'implausible' remains to be seen, as such a malleable standard will have to be worked out in practice.").

82. See, e.g., Kevin M. Clermont \& Stephen C. Yeazell, Inventing Tests, Destabilizing Systems, 95 IOWA L. REV. 821, 823 (2010); David L. Noll, The Indeterminacy of Iqbal, 99 GEo. L.J. 117, 119 \& n.12 (2010) (noting that "[c]ommentators have been sharply critical" and listing articles). However, reactions to Twombly and Iqbal are not entirely negative. See Dobyns v. United States, 91 Fed. Cl. 412, 428 (2010) ("Twombly and Iqbal probably are best seen merely as restating, in slightly different terms, propositions long held.... [T] hese cases do not... treat the newlyminted 'plausibility' paradigm as altering the way in which courts should apply other longstanding pleading requirements."); see also, e.g., Arthur R. Miller, From Conley to Twombly to Iqbal: A Double Play on the Federal Rules of Civil Procedure, 60 DUKE L.J. 1, 16 n.53 (2010) [hereinafter Miller, Double Play]; Steinman, supra note 73, at 1298 ("challeng[ing] the conventional wisdom that Iqbal and Twombly run roughshod over a half-century's worth of accumulated wisdom on pleading standards").

83. Miller, Double Play, supra note 82, at 19.

84. Steve Subrin, Ashcroft v. Iqbal: Contempt for Rules, Statutes, the Constitution, and Elemental Fairness, 12 NEV. L.J. 571 (2012) (referring to Iqbal) [hereinafter Subrin, Contempt for Rules].

85. Robert G. Bone, Plausibility Pleading Revisited and Revised: A Comment on Ashcroft v. Iqbal, 85 Notre Dame L. Rev. 849 (2010) [hereinafter Bone, Plausibility Pleading Revisited].

86. See, e.g., Michael C. Dorf, Iqbal and Bad Apples, 14 LEwIS \& CLARK L. Rev. 217, 218.19 (2010); Lisa Eichhorn, A Sense of Disentitlement: Frame-Shifting and Metaphor in Ashcroft v. Iqbal, 62 FLA. L. REv. 951, 964 (2010); Suzanna Sherry, Foundational Facts and Doctrinal Change, 
the defendants acted in the way they were described to have acted, and therefore "vouched" for the defendants. 87 Others have concluded that the language of Iqbal itself suggests hostility towards Iqbal, and perhaps towards other discrimination plaintiffs.88 Another scholar argues that the Court simply accepted a particular narrative about wrongdoers in government, and disregarded other possible stories. 89 Other commentators assert that Twombly and lqbal embody the Court's changing opinions about meritorious litigation in general and civil rights claims in particular.90 Finally, at least one scholar has

2011 U. ILL. L. Rev. 145, 178 (2011); Tung Yin, "I Do Not Think (Implausible) Means What You Think It Means": Iqbal v. Ashcroft and Judicial Vouching for Government Officials, 14 LEWIS \& CLARK L. REV. 203, 215 (2010).

87. For instance, Yin reads the decision in Iqbal as "as a sort of judicial vouching for the government official defendants." Yin, supra note 86, at 215. Yin has suggested that it is possible that what the Iqbal majority concluded on the facts was that Ashcroft and Muller would not have engaged in this conspiracy. See id. at 212 ("[I]t appears that the majority simply could not accept that Attorney General Ashcroft and FBI Director Mueller would have engaged in a conspiracy to discriminate against Arabs and Muslims by intentionally subjecting them to harsh treatment... for no legitimate reason. This is what the Court found implausible about Iqbal's complaint.") The Court, therefore, was asserting that it was unbelievable that Attorney General Ashcroft and FBI Director Mueller would have agreed to subject Muslims and others to harsh conditions due simply to their race, religion, or national origin, and without regard for any legitimate penal purpose. Id.

88. See Eichhorn, supra note 86, at 964 . Eichhorn writes that the Iqbal opinion represented a "shift in frame with respect to older understandings of notice pleading." Id. at 964. The Court's language "phrases its ruling against $I q b a l$ as the denial of an entitlement he has mistakenly assumed." Id. at 963-64. According to Eichhorn, "this new use of the language of entitlement transforms the plaintiff from someone who was generally presumed to have a right to proceed to discovery into someone who is being presumptuous and displaying an outsized sense of entitlement in even requesting to proceed." $I d$. at 964 . See also id. at 965 (identifying the "note of deception" in the phrase "a legal conclusion couched as a factual allegation" and in the majority's characterization of 'Iqbal's argument as seeking 'license' to 'evade' the Rules' pleading requirements") (quoting Iqbal, 556 U.S. at 1950, 1954)).

89. Iqbal itself has been portrayed as the triumph of a particular, familiar narrative over other possible meanings. Dorf argues that, in Iqbal, the Supreme Court selected a particular narrative of the fight against terrorism, which Dorf calls the "few-bad-apples narrative": According to this narrative, the "harsh treatment of detainees," including in Guantanamo, "was the work of a relatively small number of relatively low-ranking military and civilian officials who went beyond the limits of the law. The actions of these few bad apples, the narrative goes, were regrettable but not the result of official policy." Dorf, supra note 86 , at 218-19. The Court accepted this narrative by concluding "that the inference that Ashcroft and Mueller had relied on race, national origin, or religion in deciding whom to treat as high-value suspects is not plausible." Id. at 227. In other words, the Court in Iqbal was "content to imagine that prisoner abuses-in this case occurring in a federal maximum security prison in Brooklyn rather than at Abu Ghraib, Guantanamo Bay, or a CIA black site-were the work of low-level rogue actors, not high-ranking Bush Administration officials." Id. at 225. Dorf argues that the Court demonstrated that "[h] uman beings, including Supreme Court Justices, are prone to view facts as conforming to pre-existing stock scripts or narratives," and "blinded themselves to the possibility that the world did not conform to their narrative." Id. at 227-28. This reliance on familiar stock stories might cause "worry that the Court's acceptance of the few-bad-apples narrative normalizes the underlying abuses." Id. at 228 .

90. Sherry argues that the Court in Twombly and Iqbal was updating its "factual assumptions about the litigation process." Sherry, supra note 86 , at 178 . She argues that the Court appeared to be demonstrating skepticism "about the percentage of meritorious cases," in 
argued that, in announcing the plausibility standard, the Court simply ventured inadvertently into new territory without intending to break as much new ground as it did.91

Assessing the critical reaction to the decisions, one can identify several main lines of criticism.92 These critiques apply with special force to civil rights cases. ${ }^{93}$ Because each of these grounds of criticism relates to narrative theory, this Article will examine each in greater depth.

\section{A. Plausibility Forces Plaintiffs into a Difficult Position}

The first criticism of Twombly and Iqbal's plausibility standard reflects widespread concern over parties' unequal access to the information necessary to satisfy the plausibility standard, especially in civil rights cases. The standard is criticized for creating a "Catch-22" in cases in which the defendant controls the information necessary for stating a plausible claim; the plaintiffs in such cases cannot state a claim without access to critical information in the control of defendants, and they cannot proceed to discovery without stating a claim. ${ }^{94}$ Because the standard requires a plaintiff to plead sufficient facts to render his or her claim plausible, meritorious claims may never be brought to light, simply because the plaintiff cannot obtain the necessary facts without access to discovery. 95 Critics of the

line with lower court opinions "that meritless cases can impose a significant burden on defendants well before a motion for summary judgment can be effective, because of the costs of discovery." Id. at 178. Sherry also noted that it was "no coincidence that Iqbal involved a claim of discrimination," because of the Court's "recent skepticism about discrimination," including changes in assumptions "about the overall prevalence of racially discriminatory motives among American employers." Id. at 178, 166 (describing line of cases including McDonnell Douglas Corp. v. Green, 411 U.S. 792 (1973); Wards Cove Packing Co. v. Atonio, 490 U.S. 642 (1989); and St. Mary's Honor Ctr. v. Hicks, 509 U.S. 502 (1993)).

91. See, e.g., Clermont \& Yeazell, supra note 82, at 850 ("[A]ll opinions in the two cases smack more of confusion than of political motivation.").

92. Noll, supra note 82 , at $\mathbf{1 2 0 - 2 1}$.

93. Civil rights and discrimination cases present a particular puzzle for applying the plausibility standard. See Suzette M. Malveaux, The Jury (or More Accurately the Judge) Is Still Out for Civil Rights and Employment Cases Post-Iqbal, 57 N.Y.L. SCH. L. REV. 719, 722 (2013) (describing effect of Twombly and Iqbal on civil rights and discrimination cases) [hereinafter, Malveaux, The Jury Is Still Out]; see also Suzette M. Malveaux, Clearing Civil Procedural Hurdles in the Quest for Justice, 37 OHIO N.U. L. REv. 621, 622-31 (2011); Suzette M. Malveaux, Front Loading and Heavy Lifting: How Pre-Dismissal Discovery Can Address the Detrimental Effect of Iqbal on Civil Rights Cases, 14 LEwIS \& CLARK L. REv. 65, 85-102 (2010) [hereinafter Malveaux, Front Loading].

94. Charles B. Campbell, Elementary Pleading, 73 LA. L. REv. 325, 346 (2013) (describing "what scholars and some cases refer to as information asymmetry-the situation in which facts needed to plead adequately remain under a defendant's control and thus inaccessible without discovery"); Noll, supra note 82, at 120.

95. Steinman, supra note 73, at 1311; see also Miller, Double Play, supra note 82 , at 105 (noting that, because the plausibility standard "require[s] a plaintiff to have greater knowledge concerning his claim either before instituting an action or immediately thereafter, inequality of 
Twombly and Iqbal decisions have argued that the plausibility standard is so heightened that it requires a plaintiff to marshal the kind of factual support for his or her claim that previously was only required on a motion for summary judgment or, indeed, at trial.96

This pleading "Catch-22" is particularly problematic for plaintiffs alleging they were subject to discrimination or violations of civil rights, as the information those plaintiffs need to state a plausible claim may be uniquely within the possession of the defendants.97

information access during those critical time frames poses a significant-if not the most significant-problem for many people seeking affirmative relief").

96. See, e.g., Suja A. Thomas, The New Summary Judgment Motion: The Motion to Dismiss Under Iqbal and Twombly, 14 LEWIS \& CLARK L. REv. 15, 17 (2010) ("The standard for the motion to dismiss has evolved in such a way as to make the motion to dismiss the new summary judgment motion."). Cf. Richard A. Epstein, Bell Atlantic v. Twombly: How Motions to Dismiss Become (Disguised) Summary Judgments, 25 WASH. U. J.L. \& PoL'Y 61, 72 (2007) (noting that, even prior to Twombly, "the formal distinction between summary judgment and motions to dismiss on the pleadings had been eroded").

Critics of the decisions who recognize a new burden on plaintiffs at the complaint phase also argue that the extension of the "plausibility" standard from Twombly to all civil cases was an illegitimate change to the Federal Rules of Civil Procedure, short-cutting the legislative process by circumventing Rule 8 without undergoing the processes prescribed by the Rules Enabling Act. Noll, supra note 82, at 120-21; see also Cristina Calvar, "Twiqbal": A Political Tool, 37 J. LEGIS. 200, 222 (2012) ("[T]he court has used the adjudication process to circumvent the amendment process.").

Critics argue that such a dramatic change to the pleading standards should have been left to elected representatives. See Miller, Double Play, supra note 82, at 83-89 (noting criticism that "with Twombly and Iqbal, the Court may have forsaken its long-held commitment to the rulemaking process by reformulating the Rules' pleading and motion-to-dismiss standards by judicial fiat"). See also Subrin, Contempt for Rules, supra note 84, at 577. In particular, critics claim the decision embodied in Twombly and Iqbal about the need to reduce the burdens of discovery on defendants was a political judgment the Court was ill-suited to make; a decision about whether the burdens of discovery in meritless lawsuits have become too much for defendants to be required to bear would have been better left to congressional action following formal hearings and testimony. See Bone, Plausibility Pleading Revisited, supra note 85, at 851 (arguing that the decision to screen against weakly pleaded, rather than completely nonmeritorious suits, involves policy decisions the courts are ill-equipped to handle); Clermont \& Yeazell, supra note 82, at $\mathbf{8 5 0}$ (arguing that "rulemaking bodies should have hosted" a discussion on whether pleading rules should more vigorously screen for meritorious claims); Spencer, Plausibility Pleading, supra note 5, at 454 ("[T]he rule amendment process is preferable [to judicial revision of pleading standards] because it is a much more democratic, transparent, and accountable method of making changes to the Federal Rules."); see also Subrin, Contempt for Rules, supra note 84, at 579 (noting that "[t]here is no evidence that discovery is an unreasonable burden in the vast majority of cases. In fact, the evidence is to the contrary ....").

97. See Subrin, Contempt for Rules, supra note 84 , at 580 ("Plaintiffs, particularly in... discrimination cases where discovery is frequently needed to determine the facts, states of mind and otherwise, that reside in the defendants' minds and files, and in the minds and files of defendant-friendly witnesses, will be left out in the cold."); see also Howard M. Wasserman, Iqbal, Procedural Mismatches, and Civil Rights Litigation, 14 LEWIS \& ClaRK L. REv. 157, 168 (2010) ('The two most notable pieces of information that are beyond plaintiff's reach [in constitutional and civil rights litigation] at the outset are evidence of defendants' subjective state of mind and evidence of defendants' private, behind-closed-doors conduct."). Wasserman highlights what he calls "the paradox" of civil rights pleading: A plaintiff must draft a factually sufficient complaint before he or she has access to the very discovery that will supply many of the key facts of his or her claim. Id. at 168. See also Seiner, After Iqbal, supra note 73, at 228 (noting the challenges of a "more complex and undefined plausibility test" for employment 
Proving intent in an employment discrimination case, for instance, is difficult.98 Due to unequal access to key information and lack of formal discovery procedures prior to filing a complaint, plaintiffs in civil rights cases often tell a story at the complaint phase that includes facts making legal and illegal behavior equally plausible. 99

In the absence of formal pre-filing discovery available under the Federal Rules, academics have suggested various mechanisms for remedying this information imbalance, from the readily-available to the novel, including use of informal pre-filing discovery and more reliance on FOIA requests.100 For instance, several commentators have

discrimination plaintiffs, since "Iqbal creates an arduous burden for Title VII plaintiffs by mandating that allegations of discriminatory intent cannot be general or conclusory and must be made with the proper factual support").

98. See Seiner, After Iqbal, supra note 73, at 195-96 ("Proving intent in an employmentdiscrimination case is certainly a tricky endeavor, and pleading intent after Iqbal may be even trickier. What it means to plausibly plead discriminatory intent under Title VIl remains an open question and will likely be a matter for the courts to resolve."). See also Charles A. Sullivan, Plausibly Pleading Employment Discrimination, 52 WM. \& MARY L. REV. 1613, 1642 (2011). Describing how the facts in an employment discrimination case are uniquely outside the grasp of the plaintiff, Sullivan writes: "What the putative plaintiff will rarely 'know' is the employer's intent in taking the challenged action.... Title VII and other antidiscrimination statutes do not bar particular conduct-such as failure to hire or a decision to discharge. Such actions are perfectly acceptable unless motivated by discriminatory intent." Id.

99. See Malveaux, The Jury Is Still Out, supra note 93, at 725-26 ("[D]iscriminatory intent is often difficult, if not impossible, to unearth before the parties have had some discovery. Discrimination has become more subtle and institutional. It can be harder to detect because it is less overt and transparent; instead it takes the form of stereotypes and unconscious bias.").

100. Wasserman, supra note 97 , at 168 . Suggestions for reforming discovery processes to aid plaintiffs in meeting the plausibility standard may strike readers as ironic, especially since the Court's decision in Twombly indeed appeared motivated in part by a desire to avoid excessive discovery costs. See Bell Atl. Corp. v. Twombly, 550 U.S. 544, 557-58 (2007) (citing Car Carriers, Inc. v. Ford Motor Co., 745 F.2d 1101, 1106 (7th Cir. 1984) ("[T]he costs of modern federal antitrust litigation and the increasing caseload of the federal courts counsel against sending the parties into discovery when there is no reasonable likelihood that the plaintiffs can construct a claim from the events related in the complaint")); see also Miller, Double Play, supra note 82, at 61-62 ("Twombly justified establishing plausibility pleading on the basis of assumptions about excessive discovery costs for these organizations and the threat of extortionate settlements.").

Although the Court's adoption of the plausibility standard has been praised for its potential to eliminate excessive discovery costs on litigants and burdens on trial courts, see, e.g., In re Text Messaging Antitrust Litig., 630 F.3d 622, 625 (7th Cir. 2010) (describing Twombly, "even more clearly than its successor" Iqbal, as "designed to spare defendants the expense of responding to bulky, burdensome discovery unless the complaint provides enough information to enable an inference that the suit has sufficient merit to warrant putting the defendant to the burden of responding to at least a limited discovery demand"), that argument supposes that the plausibility standard actually screens successfully for meritorious versus nonmeritorious claims, see Steinman, supra note 73 , at 1312 . In fact, the plausibility standard gives no such guarantees of its success rate, particularly in light of its subjectivity. Id.; see also Lonny S. Hoffman, Burn Up the Chaff with Unquenchable Fire: What Two Doctrinal Intersections Can Teach Us About Judicial Power over Pleadings, 88 B.U. L. REV. 1217, 1233 (2008) [hereinafter Hoffman, Doctrinal Intersections] [noting that, to the extent the decisions were motivated by attention to discovery abuses, the Court's approach was "one-sided," focusing "only on the problem of discovery abuse by reference to the incidence of nonmeritorious litigation ('groundless' is the Court's word of choice) brought by plaintiffs"). Indeed, some research suggests that the standard may not 
proposed a system of limited, formal pre-filing discovery.101 However, unless and until a solution can be implemented, litigants facing an information asymmetry still must deal with the plausibility standard, and a greater reliance on narrative, as discussed below, is a promising solution.

\section{B. Plausibility is an Idiosyncratic, Amorphous Standard}

The second line of criticism of the plausibility standard embodies the widely-shared impression that directing judges to apply their "judicial experience and common sense"102 confers "virtually unbridled discretion"103 on a district court judge to determine whether the allegations in a complaint "ring true" to that particular judge.104 Along these lines, the plausibility standard has been characterized as impracticably open-ended, conferring broad

alleviate concerns about abusive discovery costs and drawn-out meritless litigation. See, e.g. Calvar, supra note 96, at 217 (explaining theories "that the recent standard actually increases [litigation] costs and prolongs efforts"].

101. See Miller, Double Play, supra note 82, at 105 \& n.406 (suggesting some "form of limited preinstitution discovery to provide access to critical information"). More intensive proposed changes include permitting targeted or "flashlight" discovery after a motion to dismiss is filed. See id. at 107 \& n.414. Miller views such "early, limited, and carefully sequenced discovery" as a possible "fruitful middle ground for evaluating challenges to cases that lie between the traditional Rule $12(\mathrm{~b})(6)$ motion based on the complaint's legal or notice-giving insufficiency and a motion based on the complaint's failure to meet the factual plausibility precepts of Twombly and Iqbal." Id. A carefully-constructed procedure could "bring some equilibrium to the burdens on the parties at the pleading and motion-to-dismiss phases of litigation" but would also tax judicial resources and require rule amendment. See id. at 118-25. Such a course would require either an amendment of Rule 27 or would force litigants to rely on state pre-suit discovery provisions of different scope. Id. at 105-06. It would also subject litigants to a new procedural hurdle (showing the need for discovery) and tax judicial resources. Id. at 106. See also Jonathan D. Frankel, May We Plead the Court? Twombly, Iqbal, and the "New" Practice of Pleading, 38 HofSTRA L. REv. 1191, 1194 (2010).

Other proposals for correcting the information asymmetry problem posed by the plausibility standard have included changes to the federal courts' system of case management. Miller, Double Play, supra note 82, at 114. However, proposals for "tracking" cases based on the substantive governing law to allow different kinds of discovery would undoubtedly require an abandonment of the Civil Rules' signature characteristic of transusbstantivity. Id. at 118.

Finally, some have suggested abrogating Twombly and Iqbal entirely by rule by adding additional classes of cases requiring heightened pleading to Rule 9 , or amending the Federal Rules and the Federal Forms to better reflect pleading rules and provide more instructive sample pleadings. See Clermont \& Yeazell, supra note 82, at 855-57 (Under the Rule 9 approach, which would implement a familiar "particularity" requirement, "courts can sensibly demand factual detail, whereas testing for factual convincingness without an evidential basis is inherently destabilizing.").

102. Iqbal, 556 U.S. at 679.

103. Access to Justice Denied: Hearing on Ashcroft v. Iqbal Before the Subcomm. on the Constitution, Civil Rights, and Civil Liberties of the H. Comm. on the Judiciary, 111th Cong. 9 (2009) [hereinafter Hearing] (statement of Prof. Arthur M. Miller), http://judiciary.house.gov/hearings/pdf/Miller091027.pdf.

104. See Comment, Pleading Standards, 123 HARV. L. REv. 252, 262 (2009) (quoting Adam Liptak, Case About 9/11 Could Lead to a Broad Shift on Civil Lawsuits, N.Y. TIMES, July 21, 2009, at A10); see also Noll, supra note 82 , at 120 \& n.18. 
discretion on judges to enforce a slippery standard.105

According to Professor Miller, concepts of common sense and judicial experience are "highly subjective concepts largely devoid of accepted-let alone universal-meaning."106 Certainly, judges' common sense and experience could be considered "extra-pleading... factors." 107 The Court's apparent attempt to mask this shift to subjectivity by using language that suggests an objective measurement compounds, for some, the frustration. 108

The direction to apply judicial experience and common sense may matter most in civil rights cases, which will often require a judge, assessing whether a pleading will survive a motion to dismiss, to gauge the plausibility of allegations that a defendant acted with discriminatory intent.109 Critics of the plausibility standard express concern that inviting judges to incorporate their own experiences risks preferencing a dominant, majority perspective over outsider voices-which threatens the role of the federal judiciary as a protector of minority rights. 110 As this criticism goes, a standard based

105. Noll, supra note 82, at 120. See also Ramzi Kassem, Implausible Realities: Iqbal's Entrenchment of Majority Group Skepticism Towards Discrimination Claims, 114 PENN ST. L. REV. 1443, 1451 (2010) (calling "plausibility" and "common sense" concepts that are "malleable and ill-defined"); Malveaux, The Jury Is Still Out, supra note 93, at 723-24 (alleging the plausibility standard "fails to give judges enough guidance on how to determine whether a complaint should be dismissed," "create[s] unpredictability, lack of uniformity, and confusion," and threatens "excessive subjectivity ... depending ... on the identity of the judge").

106. Hearing, supra note 103, at 9 (statement of Prof. Arthur M. Miller). See also Clermont \& Yeazell, supra note 82 , at 840 ("Judges will vary in finding nonconclusory allegations of a complaint implausible after considering the specific 'context' of the case and applying 'judicial experience and common sense." "); Hillel Y. Levin, Iqbal, Twombly, and the Lessons of the Celotex Trilogy, 14 LEWIS \& CLARK L. REV. 143, 148 (2010) ("Justice Kennedy's explanation of the role of the judge in Iqbal is, depending on your view of this sort of thing, refreshingly candid or stunningly lawless (or perhaps both).").

107. Hearing, supra note 103, at 8 (statement of Prof. Arthur M. Miller).

108. With the talk of sheerness, heft, and thick pleading, Iqbal's metaphors of pleading were ripe for examination in a law review article. See Eichhorn, supra note 86, at 967-69. Eichhorn argues that the conceptual metaphors the Court created in Iqbal, treating factual allegations as having physical mass, associated the plausibility inquiry with "notions of consistency and objectivity," while obscuring the enormous amount of discretion given to judges under the standard. Id. at 969. Similarly, Eichhorn points out that "both the Twombly and Iqbal opinions speak in terms of a fixed line separating the merely possible from the plausible." Id. at 969. The "fixed line" metaphor also appears to modulate the discretion given to judges under the plausibility standard, suggesting "that it is possible to differentiate consistently between the possible and the plausible; one need only look to see whether the allegations have crossed some agreed-upon, fixed boundary." Id. at 969 . According to Eichhorn, such metaphors "downplay the substantive shift in the law, reinforcing the notion that the Court's analysis is simply a fair and consistent application of precedent, rather than a usurpation of the Congressional power to change the Federal Rules." Id. at 974. See also Kassem, supra note 105, at 1453.

109. See, e.g., Kassem, supra note 105, at 1453.

110. Malveaux notes the evidence of "significant differences in perception among racial groups over the existence and pervasiveness of race discrimination" and posits that "some judges, like many Americans, may operate from the presumption that race discrimination is a thing of the past," leading the judge "to conclude that, based on the facts before him, intentional 
on experience cannot help but incorporate beliefs judges formed as members of a socially and politically elite group.111 Reference to judges' own sense about the world may be particularly problematic if judges hold inaccurate beliefs about the frequency or likelihood of discrimination in society. 112

Similarly, the term "plausibility" itself is relatively novel to pleading and procedure cases, 113 and therefore, poorly defined.114 The indeterminacy of the term invites idiosyncratic and even political interpretations. 115

Without firmer direction from the Supreme Court, it will be up to judges to assess how to apply their "judicial experience and common sense" to assess plausibility and gauge the likelihood of other alternative explanations. 116 This ambiguity also creates costs for the

discrimination is implausible, especially in light of alternative explanations available." Malveaux, The Jury Is Still Out, supra note 93, at 724. See also Kassem, supra note 105, at 1446.

111. A. Benjamin Spencer, lqbal and the Slide Toward Restrictive Procedure, 14 LEwIS \& CLARK L. REV. 185, 197 (2010) [hereinafter Spencer, Restrictive Procedure] (arguing that the plausibility standard reveals "the institutional biases of the Justices, as elite insiders with various presumptions about the conduct and motives of other fellow societal elites"). Spencer also identifies an intransigence, not necessarily born of elitism but that bespeaks an unwillingness to consider others' stories, which has negative effects on plaintiffs, including those from historically disadvantaged social groups. Id. at 199-201 ("What we see in these opinions is the Justices' willingness to prefer their own interpretation of facts over other interpretations, leaving no room for the possibility that other understandings may have validity.... Such a perspective ends up favoring civil defendants, at least when they are arrayed as adversaries against members of various societal out-groups.").

112. See Spencer, Restrictive Procedure, supra note 111, at 198. Spencer notes that "the Court's 'experience and common sense' is not universal but rather is shaped by their perspective and bias as societal elites who suppose that such discrimination is rare." Id. Sherry writes that, "[t]o the extent that the Court has come to believe both that invidious discrimination is no longer the most likely explanation for adverse employment actions, and that litigation is too burdensome to trust the judgment of plaintiffs and their lawyers," anti-discrimination plaintiffs are at a high risk. Sherry, supra note 86, at 182-83. See also Victor D. Quintanilla, Beyond Common Sense: A Social Psychological Study of Iqbal's Effect On Claims of Race Discrimination, 17 MICH. J. RACE \& L. 1, 2 (2011). Quintanilla explains that majority group members believe (wrongfully) that "discrimination is no longer a problem for minority group members in American society," and "that racism is a psychopathology-that racists act in blatant and overt ways," rather than encompassing behaviors both overt and subtle. Id. at 55.

113. See Clermont \& Yeazell, supra note 82, at 851-52 ("Not only was [the term "plausibility"] new to the world of pleading, it was largely new to the world of civil procedure.").

114. See Reinert, Pleading as Information Forcing, supra note 74, at 8 ("Plausibility is something more than mere possibility or conceivability, the Court has told us, but something less than a preponderance test"); see also Hoffman, Doctrinal Intersections, supra note 100, at 1257 ("Virtually everyone (except, perhaps, the five Justices in the majority in Twombly) regards plausibility as an ambiguous standard.").

115. Subrin, Contempt for Rules, supra note 84, 578 ("But 1 think it is incontestable that these terms-conclusory and plausible-are highly fluid and non-defining, and that different judges calling on their own common sense, experience-and yes, their political views-will surely interpret the terms differently in the cases before them."). See also Hearing, supra note 103, at 9 (statement of Prof. Arthur M. Miller).

116. For instance, in a dissent, Judge Richard Posner of the Seventh Circuit developed a numerical account of plausibility: 
judicial system, as the application of an ambiguous standard is likely to be challenged and require attention on appeal.117

Furthermore, moving beyond the question of the legitimacy of incorporating judges' own lived experience into a pleading standard, abandoning the familiar "no set of facts" standard creates widespread confusion among litigants, lower courts and legal academics.118 There is even confusion over whether the federal forms themselves, which under Federal Rule of Civil Procedure 84 suffice to meet the requirements of Rule 8 , would satisfy the plausibility standard.119

In contrast to this criticism, some have argued that the ambiguity and grant of discretion embodied in the plausibility standard is beneficial or at least defensible.120 Ultimately, regardless of whether "judicial experience and common sense" leads to salutary or detrimental effects, the reality of the plausibility standard is that litigants must account for the interplay between pleadings and the characteristics of their judicial audience, and judges must determine how to apply their judicial experience and common sense-both tasks that narrative can help accomplish.

In statistics the range of probabilities is from 0 to 1 , and therefore encompasses "sheer possibility" along with "plausibility." It seems (no stronger word is possible) that what the Court was driving at was that even if the district judge doesn't think a plaintiff's case is more likely than not to be a winner (that is, doesn't think $p>.5$ ), as long as it is substantially justified that's enough to avert dismissal.

Swanson v. Citibank, N.A., 614 F.3d 400, 411 (7th Cir. 2010) (Posner, J., dissenting). Notably, this direction to rely on judicial experience and common sense came after well-recognized public debate over the propriety of judges' own life experiences informing their decisions. See, e.g., Margaret M. Zwisler \& Amanda P. Reeves, The Search for Clarity in Federal Pleading Standards: Are We Close to Limiting the Intended (and Unintended) Consequences of Twombly and lqbal?, 13 SEDONA CONF. J. 135, 136 (2012) (noting that "[t]he Senate Judiciary Committee pilloried both Elena Kagan and Sonia Sotomayor during their confirmation hearings for suggesting that a judge's own experience should inform his or her decisions").

117. See Hoffman, Doctrinal Intersections, supra note 100, at 1258 (noting that the ambiguity in the plausibility standard means imposing additional costs on everyone, thus carrying serious practical and social consequences).

118. See Hearing, supra note 103, at 19 (statement of Prof. Arthur M. Miller) (referring to "confusion and uncertainties" Twombly and Iqbal have generated).

119. See, e.g., A. Benjamin Spencer, Understanding Pleading Doctrine, $108 \mathrm{MICH}$. L. REV. 1, 12 (2009) [hereinafter Spencer, Understanding Pleading Doctrine] ("Do these forms really comply with the Twombly standard? ... Twombly suggested that conclusory terms could not be made to do the work of actual fact allegations."); Steinman, supra note 73, at 1310 ("The continued vitality of classic pre-Twombly authorities (e.g., Form 11 and Swierkiewicz) is in doubt.").

120. See, e.g., Mark Moller, Procedure's Ambiguity, 86 IND. L.J. 645, 647 (2011) (arguing that "opaque" decisions like Twombly and Iqbal "create space for lower courts to adopt a blend of different, conflicting interpretations of a statute (or procedure)-yielding an average result that compromises, or 'trims,' between competing preferences"); see also Kassem, supra note 105, at 1446 (noting that judicial exercise of discretion is a central part of the American court system). 


\section{The Plausibility Standard Reduces Access To Justice}

Finally, the plausibility standard has been criticized because pleading standards are central to justice 121 and the plausibility standard threatens to restrict access to justice generally.122 Under this line of criticism, the new, more demanding plausibility standard is problematic both because it violates the open spirit of the Federal Rules 123 and because it leads to less effective enforcement and vindication of important constitutional and other federal civil rights. 124

Critics of the plausibility standard warn that the more demanding standard will both eliminate meritorious suits 125 and have a chilling effect on the filing of suits in the first place.126 Overall, critics claim, there is no reason to think the plausibility standard is so much more efficient (as compared to the Conley-era formulation) that it is worth the risk of barring or chilling meritorious claims.127

Critics voice a particular concern about losing access to justice in civil rights cases because the American justice system relies on private enforcement of civil rights laws.128 Increasing obstacles to

121. See, e.g., Steinman, supra note 73 , at 1294 ("If a plaintiff seeking judicial redress is unable to provide an adequate 'statement of the claim' at the pleadings phase, then that claim is effectively stillborn.").

122. See, e.g., Campbell, supra note 94, at 347 ; Levin, supra note 106, at 146.

123. See, e.g., Surowitz v. Hilton Hotels Corp., 383 U.S. 363, 373 (1966) ("If rules of procedure work as they should in an honest and fair judicial system, they not only permit, but should as nearly as possible guarantee that bona fide complaints be carried to an adjudication on the merits."); see also, e.g., Miller, Double Play, supra note 82, at 3-4 (noting that the 1938 "Federal Rules reshaped civil litigation to reflect core values of citizen access to the justice system and adjudication on the merits based on a full disclosure of relevant information"); Spencer, Plausibility Pleading, supra note 5, at 479-80 (decrying challenge to the "liberal ethos" of Federal Rules and subsequent jurisprudence in Twombly and lqbal).

124. Wasserman, supra note 97, at 161 ("The predictable result [of Twombly and lqbal] will be a significant decrease in enforcement and vindication of federal constitutional and civil rights, and of the values and principles underlying those rights.").

125. Miller, Double Play, supra note 82 , at 71 (arguing the plausibility standard "will result in some possibly meritorious cases being terminated under Rule 12(b)(6), thereby reducing citizens' ability to employ the nation's courts in a meaningful fashion"); see also A. Benjamin Spencer, Pleading Civil Rights Claims in the Post-Conley Era, 52 How. L.J. 99, 160 (2008) [hereinafter Spencer, Pleading Civil Rights Claims] (noting that a motion to dismiss based on the plausibility standard "will weed out claims that are merely suspected of lacking merit rather than reserving dismissal only for those claims that are certain to lack merit").

126. Miller, Double Play, supra note 82 , at 71 (arguing the plausibility standard "will chill a potential plaintiff's or lawyer's willingness to institute an action"); Levin, supra note 106, at 152 ("[T]he Supreme Court's plausibility standard is extraordinarily vague, making it difficult for a party to judge whether a potential lawsuit is worth bringing.").

127. Alexander A. Reinert, The Costs of Heightened Pleading, 86 IND. L.). 119, 125 (2011) ("There is ... no empirical basis supporting the assumption that heightened pleading standards [such as 'plausibility'] are more efficient filters than Conley's notice pleading standard.").

128. See Wasserman, supra note 97, at 171; see also id. at 174 ("[P]rocedural rules should support, rather than undermine, plaintiffs who act as private attorneys general and seek to enforce the Constitution, ensure government accountability, and benefit the public at large."). 
justice for civil rights plaintiffs is of particular concern because the federal courts, traditionally insulated from majoritarian pressure, are usually vindicators for those claiming discrimination. 129 This concern is especially serious because contemporary forms of prejudice may be more subtle than earlier instances, yet no less deserving of recompense. 130 As well, compromising enforcement and deterrence is at odds with the goals of anti-discrimination laws. 131

The debate over the effect of the plausibility standard on access to justice is more than academic. Empirical evidence suggests that the plausibility standard is having a negative effect on plaintiffs, particularly civil rights plaintiffs; the plausibility standard has had an effect on dismissal rates of civil cases, including civil rights and discrimination cases, although the magnitude of the effect is difficult to pinpoint.132 Additional empirical evidence shows that motions to dismiss in civil rights cases may be decided differently depending on the race of the plaintiff and/or the race of the judge. 133 As the picture

129. See, e.g., United States v. Carolene Prods. Co., 304 U.S. 144, 152 n.4 (1938); JoHN HART ELY, DEMOCRACY AND DISTRUST 151-52 (1980); see also Kassem, supra note 105, at 1445 ("[T] he courts are minority groups' most natural allies in the United States' tripartite constitutional arrangement.); Spencer, Pleading Civil Rights Claims, supra note 125, at 100 ("For some time now, members of minority or disadvantaged groups in the United States have used the federal courts as the forum in which they seek remedies for harmful discriminatory conduct and obtain protection against prospective harm of this kind."). One commentator has argued that two seminal civil rights cases would have turned out differently under the plausibility standard. Brooke D. Coleman, What If?: A Study of Seminal Cases As If Decided Under A Twombly/Iqbal Regime, 90 OR. L. REv. 1147, 1156 (2012) (discussing Regents of the University of California $v$. Bakke, 438 U.S. 265 (1978), and Price Waterhouse v. Hopkins, 490 U.S. 228 (1989)). Among other things, Coleman describes the complaint in Bakke, at four pages, as "sparse." Id. at 1159. Similarly, Hopkins' complaint, while containing numerous details about her work, had very little factual information that would show she had been discriminated on the basis of sex; Coleman concludes that "it is unlikely that [Hopkins] could have amended her complaint to add the wellpleaded facts necessary to successfully state a claim under Twombly and Iqbal." Id. at 1163. Coleman also suggests that, with respect to a host of key civil rights cases, "there is a good argument that each of these complaints might not have survived a motion to dismiss in a Twombly/lqbal regime." Id. at 1180 n.6.

130. Quintanilla predicts that the plausibility standard will have a "profound" effect on federal nondiscrimination law, limiting protections against forms of "subtle prejudice" and "fail[ing] to protect the members of stigmatized groups who most need legal protection against modern forms of prejudice." Quintanilla, supra note 112, at 59.

131. There is well-documented concern over the potential chilling effect and exclusionary effect on civil rights and discrimination suits in particular following the plausibility standard. See, e.g., Malveaux, Front Loading, supra note 93, at 101 ("[T]he new plausibility pleadings standard compromises civil rights enforcement and deterrence objectives. Potentially meritorious civil rights claims will be prevented from being heard in federal court, a forum plaintiffs have historically relied upon for relief. Meanwhile, those who discriminate will enjoy a windfall.").

132. See, e.g., Malveaux, The Jury Is Still Out, supra note 93, at 720 (noting that "if potentially meritorious civil rights and employment discrimination cases are dismissed prematurely, law enforcement and deterrence will be sacrificed for expediency and efficiency," and concluding that " $[t]$ he answer to this question is that we don't know yet").

133. Studying cases in the $\mathbf{1 8}$ months before and after Iqbal, Quintanilla found statistically 
of motions to dismiss post-Twombly and Iqbal is coming into focus, it is not encouraging for civil rights plaintiffs.

Following Twombly and Iqbal, more defendants are filing motions under Rule 12(b)(6) (to dismiss for failure to state a claim).134 The rate of filing for motions to dismiss has also increased for civil rights cases.135 There is general agreement that more 12(b)(6) motions are being granted post-Iqbal,136 and several studies have found that civil rights and discrimination cases have been particularly compromised by the plausibility standard. 137 One commentator has noticed that the

significant increases in dismissal of African-American plaintiffs' claims of race discrimination in the workplace and of similar claims from African-American pro se plaintiffs. Quintanilla, supra note 112 , at 5,40 ("The dismissal rate increased from $20.5 \%$ pre-Twombly to $54.6 \%$ post-Iqbal for Black plaintiffs' claims of race discrimination-a 2.66 times increase. ... For Black pro se plaintiffs' claims, the dismissal rate increased from $32.0 \%$ before Twombly to $67.3 \%$ under Iqbal, representing a 2.10 times increase."). He also found a "marginally significant trend" showing white and African-American judges apply Iqbal differently. Id. at 5, 40 ("White judges dismissed Black plaintiffs' claims of race discrimination at a higher rate $(57.5 \%)$ than did Black judges (33.3\%)."). Quintanilla finds that application of Twombly and lqbal have resulted in "increased dismissals of Black plaintiffs' claims of race discrimination," and suggests that it "is likely that the same natural psychological processes that disadvantage Blacks are operating against other stereotyped groups at the pleading stage." Id. at 60.

134. See Joe S. Cecil ET Al., Motions to Dismiss for FaIlure to State a Claim AfTer IQbal: REPort to THE Judicial CONFEREnCE AdvisoRy COMMITTEE ON Civil Rules 8 (2011), http://www.uscourts.gov/uscourts/RulesAndPolicies/rules/Publications/motioniqbal.pdf; see also Lonny Hoffman, Twombly and Iqbal's Measure: An Assessment of the Federal Judicial Center's Study of Motions to Dismiss, 6 FED. CTS. L. REv. 1, 7 (2011) [hereinafter Hoffman, Twombly and Iqbal's Measure] (finding that "the rate of dismissal motions that were filed increased substantially" after Iqbal, as compared to the time period before Twombly); Malveaux, The Jury Is Still Out, supra note 93 , at 727-28.

135. See CECIL, supra note 134, at 8 ; see also Malveaux, The Jury Is Still Out, supra note 93, at 728. Although the study by the Federal Judicial Center (FJC) found no statistically significant increase in the rate at which motions to dismiss were granted post-plausibility, CECIL, supra note 134, at 21, the FJC study does not capture cases that have not been filed out of a chilling impact of the new plausibility standard. See Hoffman, Twombly and Iqbal's Measure, supra note 134, at 27-30; see also Patricia Hatamyar Moore, An Updated Quantitative Study of Iqbal's Impact on 12(b)(6) Motions, 46 U. RICH. L. REV. 603, 609 (2012). The FJC study also does not reflect whether cases were dismissed for factual insufficiency. Hoffman, Twombly and Iqbal's Measure, supra note 134, at 30-31. Finally, the study cannot reflect whether cases that were indeed dismissed were in fact meritorious. Id. at 30. See also Moore, supra, at 654 ("Does the elevated rate of granting 12(b)(6) motions under Iqbal happen mainly in those cases where it 'should' happen? I cannot make a normative judgment here as to whether the cases that were entirely dismissed on the grant of a 12(b)(6) motion under Iqbal were cases that should be allowed to go forward as a matter of right.") (internal quotation omitted); Malveaux, The Jury Is Still Out, supra note 93, at 733-39.

136. See CECIL, supra note 134, at 22; see also Malveaux, The Jury Is Still Out, supra note 93, at 739; Moore, supra note 135 , at 605.

137. See Raymond H. Brescia, The Iqbal Effect: The Impact of New Pleading Standards in Employment and Housing Discrimination Litigation, $100 \mathrm{KY}$. L.J. 235, 284 (2012) (finding an "lqbal effect" in civil rights actions involving allegations of employment and/or housing discrimination; "[n]ot only were cases dismissed at a higher rate since Iqbal, but also, plaintiffs were forced to defend themselves on these grounds far more often than before, meaning significant transactions costs"); Moore, supra note 135, at 605 (finding a statistically significant increased "risk of a 12(b)(6) motion being granted without leave to amend, compared to being denied... under Iqbal than under Conley," greater "odds of the case being entirely dismissed 
lower courts are not deploying the "plausibility" standard the way the Supreme Court ostensibly intended; while they are dismissing more cases, they are not analyzing the plausibility standard in a substantive way. 138

It is worth noting that the Twombly and Iqbal cases and the plausibility standard are all part of a larger trend towards limiting access throughout the federal court system.139 As well, although most commentary focuses on the Supreme Court's agency in creating these negative effects, others have identified that the Supreme Court's pronouncement of the plausibility standard only reflects the adoption of practices that had already been thriving in the lower federal courts. 140

Of course, the foregoing criticisms overlap and interplay with one another. For instance, the restriction of access to justice relates to the problem of information asymmetry, in that the heightened pleading standard, when combined with information asymmetry, exhibits a chilling effect on lawsuits.141

As discussed further below, each of these concerns can be resolved by applying narrative theory to the plausibility puzzle. This is a

upon the grant of a 12(b)(6) motion without leave to amend ... under lqbal than under Conley," and a higher rate of dismissal "post-lqbal than pre-Twombly" for constitutional civil rights cases); Joseph A. Seiner, Pleading Disability, 51 B.C. L. REv. 95, 120 (2010) [hereinafter Seiner, Pleading Disability] (finding "a higher percentage of district court opinions granting motions to dismiss in the disability context in the year following the Bell Atlantic decision compared to the year prior to the Supreme Court case"); Joseph A. Seiner, The Trouble with Twombly: A Proposed Pleading Standard for Employment Discrimination Cases, 2009 U. ILL. L. REV. 1011, 1029 (2009) [hereinafter Seiner, The Trouble with Twombly] (finding "a higher rate of dismissals in Title VII opinions issued after Twombly"); see also Malveaux, The Jury Is Still Out, supra note 93, at 74143.

138. See Brescia, supra note 137, at 285. Brescia studied civil rights actions involving allegations of employment and/or housing discrimination and specifically considered "how lower courts are deploying the plausibility standard," both by looking at courts' mention of more plausible alternatives and at "the extent to which judges appear to be applying their experience and common sense to solve pleading challenges." $I d$. Brescia found that district courts "rarely referred to the plausibility standard in any substantive way at all"; "did not deploy a "more plausible' rubric to test the specificity of pleadings"; and "almost never - at least not explicitlyreferred to their own experience and common sense, as urged by the Court, in testing those pleadings." Id. at 285. Nonetheless, Brescia concluded that "[t]he fact that district courts did not use Twombly or lqbal in the manner contemplated by the Court, yet dismissed these cases more frequently, suggests that at least some judges may feel emboldened to dismiss cases after Iqbal regardless of the standard they may or may not invoke." $I d$. at 286.

139. Levin, supra note 106 , at $146-48$.

140. Id. at 149 ("At most, the Supreme Court has been a lag indicator for what was already happening in the lower courts."). See also Fairman, Notice Pleading, supra note 10, at 998-1059 (noting range of cases in which trial and appellate courts imposed heightened pleading standards in contravention of explicit Supreme Court precedent).

141. See Hoffman, Doctrinal Intersections, supra note 100, at 1263 ("[B]ecause of information asymmetries, when a heightened pleading standard is imposed, some meritorious cases will not be filed and, further, some that are filed will be dismissed (or settled for marginal value)."). 
position few commentators have explored. Reacting to the new standard, Professor Miller predicted that "we may be entering an age of storytelling pleading."142 However, he also asked whether the tales "will ... be happy or sad ones." 143 As this Article shall explain in the next two sections, the application of narrative theory and storytelling techniques to pleading in the post-Twombly and Iqbal world can ensure that the story of plausibility pleading has a better chance at a happy ending.

\section{NARRATIVE THEORY AND NARRATIVE TOOLS}

Narrative theory answers the complex question of why narratives are persuasive. Narrative theory also seeks to explain the characteristics that every narrative possesses and how those characteristics function. The persuasive characteristics of narratives imbue narratives with plausibility. For this and numerous other reasons, narrative theory holds great promise for meeting the plausibility standard.

A narrative is, in short, a story. 144 Narrative theory studies not only the composition, but also the transmission and reception of stories. 145 The concept of the "narrative transaction" focuses on the effect of the story on the audience, recognizing that, in understanding a story, "all ... readers and listeners ... have to work with is the presentation of events in the vehicle of narrative discourse." 146

This Article will explore the characteristics of narrative that make it so persuasive, and then will briefly recount the elements that must be present in a narrative, as well as narrative techniques that can enrich a narrative's persuasiveness.

\section{A. Narrative Rationality: What Makes Narratives Persuasive?}

Narratives are an innately human way of presenting and understanding experiences. 147 Cognitive research reveals that humans

142. Miller, Double Play, supra note 82 , at 36 .

143. Id.

144. By way of more detailed definition, a narrative is "a telling of some true or fictitious event or connected sequence of events, recounted by a narrator to a narratee ... in which the events are selected and arranged in a particular order (the plot)." CHRIS BALDICK, THE CONCISE OXFORD DICTIONARY OF LITERARY TERMS 145 (1990).

145. See Paul Gewirtz, Victims and Voyeurs: Two Narrative Problems at the Criminal Trial, in LAW'S STORIES: NARRATIVE AND RHETORIC IN LAW 135, 143 (Peter Brooks \& Paul Gewirtz eds., 1996).

146. Peter Brooks, The Law as Narrative and Rhetoric, in LAW'S STORIES: NARRATIVE AND RHETORIC IN LAW 14, 17 (Peter Brooks \& Paul Gewirtz eds., 1996).

147. See Anthony G. AmSterdam \& Jerome BrunER, Minding the LAW 114 (2000) ("[N]o culture, no language group is without stories. ... It seems almost as if humankind is unable to get on without stories. Knowing how to tell them and to comprehend them may be part of the 
make sense of experiences by drawing on "interpretive frameworks" called "schemas." 148 A schema is a framework that contains general knowledge about a particular subject, including relationships between events and occurrences.149 Schemas allow an individual to process information about his social environment, and they guide perception, memory and inference.150

Individuals combine schemas to tell stories (or narratives), which function as "an interpretative framework in which multiple schema are operating at once." 151 Cognitive scientists have discovered that humans have a tendency to "organize experience into narrative form." 152

Similarly, on a societal level, groups tell stories that give meaning to complex experiences, through the cultural concept of "stock stories."153 Humans draw on a pool of "stock stories" when faced with a new experience.154 Stock stories can be considered cultural master stories or myths that give meaning to social experiences.155 "Stock stories" assist a person in understanding the new experience, by giving him or her tools to assess and interpret the circumstances and shape judgment regarding the experience. 156 Thus, stock stories form an "essential part" of a culture's and an individual's judgment about the meaning of events or experiences. 157

There are, broadly, two opinions among scholars of narrative about why narrative is so universal. One camp concludes that narratives are "endogenous" - in other words, that narrative is inherent either in the

human survival kit."); David Herman, Introduction to NARRATIVE THEORY AND THE COGNITIVE SCIENCES 1, 2 (David Herman ed. 2003) ("[S]tories are found in every culture and subculture and can be viewed as a basic human strategy for coming to terms with time, process, and change."); J. Christopher Rideout, Storytelling, Narrative Rationality, and Legal Persuasion, 14 LEGAL WRITING: J. LEGAL WRITING INST. 53, 57-59 (2008).

148. Jennifer Sheppard, What If the Big Bad Wolf in All Those Fairy Tales Was Just Misunderstood?: Techniques for Maintaining Narrative Rationality While Altering Stock Stories That Are Harmful to Your Client's Case, 34 HASTINGS Comm. \& ENT. L.J. 187, 190 (2012).

149. Ronald Chen \& Jon Hanson, Categorically Biased: The Influence of Knowledge Structures on Law and Legal Theory, 77 S. CAL. L. REv. 1103, 1133 (2004).

150. Id.

151. See Jennifer Sheppard, Once Upon a Time, Happily Ever After, and In a Galaxy Far, Far Away: Using Narrative To Fill the Cognitive Gap Left by Overreliance on Pure Logic in Appellate Briefs and Motion Memoranda, 46 WILLAMETTE L. REV. 255, 260 (2009).

152. Id. at 261.

153. Id.

154. Id. at 257.

155. Id.; Sheppard, supra note 148 , at 192.

156. Sheppard, supra note 151, at 257; see also Linda L. Berger, How Embedded Knowledge Structures Affect Judicial Decision Making: A Rhetorical Analysis of Metaphor, Narrative, and Imagination in Child Custody Disputes, 18 S. CAL. INTERDISC. L.J. 259, 264 (2009) (explaining that humans "make sense out of new experiences by placing them into categories and cognitive frames called schema or scripts that emerge from prior experience").

157. Sheppard, supra note 148 , at 193. 
structure of language or in the structure of the mind.158 Others take the view that the source of narrative is not within mental or linguistic structures, but rather that narrative arises within cultures as a way of sharing human experience.159 Under this second view of narrative, narratives model "characteristic plights" and "aspirations" of a culture, and allow the culture to translate its experiences into language, representing the ordinary order of things in the culture and the proper responses to threats to that order.160 Narratives make it possible to share experiences, but they also have a practical appeal, in that they give members of the culture ways to predict, resolve, and understand events and conflicts in life. 161

Regardless of the theory one adopts about the origin of narrative, there is universal acceptance that narratives are highly persuasive. 162 Three characteristics of narrative in particular make them persuasive: (1) narrative coherence; (2) narrative correspondence; and (3) narrative fidelity. 163

\section{Narrative Coherence}

Narrative coherence deals with the "integrity of a story as a whole"164; it encompasses the structural elements of the story, including scene, act, agent, agency and purpose, and the completeness

158. Rideout, supra note 147, at 58. See also AMSTERDAM \& BRUNER, supra note 147, at 115 (Endogenous theories of narrative claim "that narrative is inherent either in the nature of the human mind, in the nature of language, or in those supposed programs alleged to run our nervous systems.").

159. AMSTERDAM \& BRUNER, supra note 147, at 116-17.

160. Id. at 117.

161. Id.

162. Narrative goes beyond pure logic, but it encompasses logical characteristics. WALTER FISHER, HUMAN COMMUNICATION AS NaRRATION: TOWARD A PHILOSOPHY OF REASON, VALUE, AND ACTION 48 (1987) (" $[N]$ arrative ratio nality does not deny the limited but necessary use of technical logic in assessing inferences or implicative forms that occur in human communication.").

163. Drawing from a deep well of narrative and communication theory, Rideout has identified the characteristics of narrative that make them persuasive. See Rideout, supra note 147, at 56; see also FISHER, supra note 162, at 5-6. The first two characteristics, coherence and correspondence, are formal properties that relate to the way the parts of a narrative relate to one another. Rideout, supra note 147 , at 56 . The final characteristic, narrative fidelity, can be considered substantive because it concerns not the structure of the narrative but its content. $I d$. Narrative fidelity encompasses a story's accuracy, with a particular concern on the judgment of the audience. Id.

164. FISHER, supra note 162 , at 105 . Narrative coherence concerns the way in which a story is told. See Rideout, supra note 147, at 64; see also W. LANCE BENNETT \& MARTHA S. FELDMAN, RECONSTRUCTING REALITY IN THE COURTROOM: JUSTICE AND JUDGMENT IN AMERICAN CULTURE 89 (1981) ("[T]he way in which a story is told will have considerable bearing on its perceived credibility regardless of the actual truth status of the story."). Similarly, Fisher considered narrative coherence a matter of "probability" and likened it to asking "whether a story "hangs together."' FISHER, supra note 162, at 47. 
and adequacy of the relationships between those elements. 165 Narrative coherence has two components: internal consistency (how well a story's parts "fit together") and completeness (how adequate the sum of the total parts of the story seems, or whether there are any gaps in the story).166

Internal consistency exists when the parts of a story relate to one another in a "quasi-logical" way; that is, the parts of the story do not contradict each other.167 Internal consistency depends, in part, upon inferences made by the audience member.168 When a reader or listener encounters a narrative, she will put together the key elements of the narrative and supply inferences between those elements.169 That is, she will make inferences to connect these related parts of the story, as long as the parts seem consistent with one another.170 On the other hand, where relationships between the key elements of a story seem ambiguous or contradictory, the story is internally inconsistent, and less persuasive. 171

To be coherent, a story must also be complete. $172 \mathrm{~A}$ complete story will contain enough information to allow the audience member reasonably to make inferences that "yield a clear interpretation for the story." 173 Among other things, a coherent story will not lack or ignore important facts, obvious counterarguments or apparently relevant issues. 174

Narrative coherence has a significant effect on the persuasiveness of a story. 175 In fact, theories about narrative coherence posit that the way in which a story is told can prevail over the evidence that supports the story. 176 Narrative coherence enhances the perceived

165. See BENNETT \& FELDMAN, supra note 164 , at 89.

166. Rideout, supra note 147 , at 64 .

167. See BERNARD S. JACKSON, LAW, FACT AND NARRATIVE COHERENCE 58 (1988); Rideout, supra note 147 , at $64-65$.

168. Rideout, supra note 147 , at 65 .

169. Id.

170. See id. at 65; BENNETT \& FELDMAN, supra note 164, at 125-41.

171. See Robert P. Burns, A Theory of THE Trial 168 (1999) ("[A] story may be implausible simply because the relationships among the key story elements are indeterminate or ambiguous.").

172. See Rideout, supra note 147, at 76 ("The other aspect of a story's coherence is its completeness, the extent to which the structure of the story contains all of its expected parts. A story may be internally consistent and yet remain unconvincing if it incomplete.").

173. BENNETT \& FELDMAN, supra note 164, at 44-45; see also Rideout, supra note 147 , at 65 .

174. FiSHER, supra note 162 , at 47 . Fisher also saw that "characterological coherence" was important to a coherent narrative. Id. "Coherence in life and in literature requires that characters behave characteristically." Id. Thus, Fisher placed great importance on "determining a character's motives" as a "prerequisite" to belief in a story. Id.

175. Rideout, supra note 147 , at 66 .

176. Id. 
credibility of a story "regardless of the actual truth status of the story." 177

\section{Narrative Correspondence}

Narratives are also persuasive because they embody a second property, that of correspondence. Narrative correspondence requires that a story fit with what the audience understands about what could happen in the ordinary course of the world.178 Narrative correspondence "is the feature of narratives that lends them much of their plausibility, that makes them structurally convincing."179 Indeed, some narrative theorists refer to the property of correspondence as "external factual plausibility"-asking "Could [the story] have happened that way?"180

Assessing narrative correspondence requires a comparison between the content of the story and the other stories that make up the stock stories of the culture, within the social knowledge of the judge or jury. 181 Audiences test the information in stories against a culture's shared understanding about human actions and the relationships of events to one another.182 Such a comparison allows the audience to determine the plausibility of a story. 183 When judging

177. BENNETT \& FELDMAN, supra note 164, at 89. Bennett and Feldman, whose work focuses on storytelling in the courtroom, found that the structural characteristics of stories, embodied in narrative coherence, were particularly important when "facts or documentary evidence are absent." Id. Bennett and Feldman give the example of politics, "when leaders present accounts of political events to the general public." Id. The structure, or coherence, of a story is also important "when a collection of facts or evidence is subject to competing interpretations." Id. They make the important point that in cases with competing facts or evidence, "it may not be the evidence that sways final judgment; judgment hinges on the structure of interpretation that provides the best fit for the evidence." Id. at 89.90 .

178. See Rideout, supra note 147 , at 66.

179. I. Christopher Rideout, A Twice Told Tale: Plausibility and Narrative Coherence in Judicial Storytelling, 10 LEGAL COMM. \& RHETORIC: JALWD 67, 71 (2013).

180. BURNS, supra note 171 , at 168.

181. Rideout relates this idea of correspondence to plausibility, noting that "[a] story will appear plausible to the extent that it manifests similarity with some model of narrative which exists within the stock of social knowledge." Rideout, supra note 147, at 67. The notion of a stock story is a familiar one in narrative theory. For instance, Amsterdam and Bruner describe the stock stories of our culture as "scripts," involving "familiar characters taking appropriate actions in typical settings"; in other words: "recurrent situations in our lives." AMSTERDAM \& BRUNER, supra note 147, at 45 . A script tells "how things actually happen and how things should happen." Id. "Established" scripts or "stock scripts" represent the "background knowledge of the culture"; they "embody normal expectations and normal practice," such as what happens when one goes to a restaurant (the waiter waits on you). Id. at 121. A narrative is a story that illustrates "what happens when a script is thrown off track" Id. at 45 . Bennett and Feldman call this the "logic of ordinary discourse," based on the "rules of empirical relationship that we know to hold true in the everyday world." BENNETT \& FELDMAN, supra note 164, at 56.

182. Rideout, supra note 179 , at $72-73$.

183. BENNETT \& FELDMAN, supra note 164 , at 48-50. Bennett and Feldman write that the audience for a story will assimilate the information in the story and test it against "the listener's 
a story, the audience looks at whether the relationships developed and inferences drawn are actually consistent with these stock stories and with their own "common sense." 184

Narrative correspondence relates to possibility-what "could" happen or "typically" happens according to cultural stock storiesand not to truth in reality. 185 The persuasive value of a narrative's correspondence "derives not from the content of the narrative as an empirical description of social reality, but rather from the social and cultural presuppositions that it conjures and with which it coheres, structurally." 186 Indeed, "the plausibility of stories has little to do with ... their actual truth status." 187 When narrative matches up to a stock story, the correspondence between the narrative and the familiar stock story adds plausibility and persuasiveness to the narrative. 188

\section{Narrative Fidelity}

Finally, to be persuasive, a story must possess narrative fidelity. 189 Narrative fidelity, the third persuasive characteristic of narrative, goes beyond the formal features of narrative-beyond a narrative's structure and its correspondence to the stock stories of the cultureand concerns the narrative's similarity to what an audience member knows to be true in the real world.190 Narrative fidelity differs from narrative correspondence because it relates not to stock stories, which are transmitted through a culture socially, but rather to an audience's real, personal experience of the world.191 Narrative fidelity refers not to the audience's belief in the actual truth of a story, but the audience's sense that the story "represent[s] accurate assertions

use of the vast store of background knowledge about social life." Id. at 50. The background knowledge allows the audience to "fill in the framework of connections" as they make inferences that will help them interpret the story. Id.

184. BURNS, supra note 171 , at 169 . This "common sense" is "a store of empirical generalizations concerning human behavior, the 'web of belief' or 'prejudgments'" that are usually "implicit" and "uncriticized" in our everyday world. Id. A story's plausibility depends on the degree of correspondence between a narrative and a "preexistent common sense (viewed as an inventory of factual generalizations with previously assigned probabilities)." Id.

185. Rideout, supra note 147 , at 67.

186. Rideout, supra note 179 , at 72 .

187. JACKSON, supra note 167 , at 63.

188. Id. at 68 .

189. Id.

190. Id. According to Fisher, the narrative principle of fidelity depends on "whether the stories they experience ring true with the stories they know to be true in their lives." FISHER, supra note 162 , at 64 .

191. Rideout, supra note 147 , at 70 . In Fisher's words, narrative fidelity is a matter of whether the parts of a story "represent accurate assertions about social reality and thereby constitute good reasons for belief or action." FISHER, supra note 162, at 105. 
about social reality." 192 Narrative fidelity thus depends, in part, on an audience's "practical judgment" 193 based on its "intuition of experience." 194

To yield these powerful characteristics of narrative, a story should be told in a way that facilitates the audience member in making the various inferences required for the tale to be persuasive.195 Below, this Article recounts the elements that a narrative must possess and surveys particular narrative techniques that help elicit the audience member's interpretation that a story possesses narrative coherence, correspondence and fidelity.196

\section{B. Narrative Techniques: How Is a Story Told?}

A narrative requires a plot, complete with beginning, middle and end.197 As the plot progresses, it must include the following elements:

(1) an initial steady state grounded in the legitimate ordinariness of things

(2) that gets disrupted by a Trouble consisting of circumstances attributable to human agency or susceptible to change by human intervention,

(3) in turn evoking efforts at redress or transformation, which succeed or fail,

(4) so that the old steady state is restored or a new (transformed) steady state is created,

(5) and the story concludes by drawing the then-and-there of the tale that has been told into the here-and-now of the telling through some coda. 198

These events must be organized into a particular structure to be cognizable as a narrative rather than a list of things. 199

Beyond the presence of these basic elements, use of narrative

192. FISHER, supra note 162 , at 105.

193. Rideout, supra note 147 , at 74 .

194. Id. (quoting Justice Holmes in Chicago, Burlington, \& Quincy Ry. v. Babcock, 204 U.S. 585, 598 (1907)).

195. See BENNETT \& FELDMAN, supra note 164, at 41.

196. See id. at 64-65.

197. AMSTERDAM \& BRUNER, supra note 147 , at 113.

198. Id. at 113-14. A narrative also needs "a case of human-like characters, being capable of willing their own actions, forming intentions, holding beliefs, having feelings." Id. at 113 . While it seems a truism that any complaint is going to have a cast of human or "human-like" characters, such is not always the case (for example, the Court's discussion of market operations in the Twombly opinion).

199. Herman, supra note 147 , at 2 ("[W] hat makes... a narrative instead of a mere agglomeration of unrelated elements... is the structure into which states and events are slotted ...."). 
techniques, such as sequence, character development, point of view, and detail, can help the writer to create the powerful characteristics of narrative-coherence, correspondence and fidelity-described above.200

The writer's decision about the order in which a story's events will be presented affects the persuasiveness and plausibility of the narrative.201 One way to begin a story is with the initial steady state (see above), moving in a default linear structure through the remaining parts of the narrative: in other words, the writer would then move to the disruption, and on through the elements of a story as set out above.202 However, other organizations may be more effective and persuasive than that linear structure.203 Altering the linear structure can effectively focus a reader on a particular fact in a story, or can hook a reader's attention.204 Effective use of sequence for persuasion can also be achieved through including a short summary of the story at the beginning of a narrative, or by following different characters through events in convergent narratives. 205

Character development helps the story or narrative feel real to the audience; an audience will experience greater empathy for some characters that feel authentic.206 Particularly in light of the existence of "correspondence bias," a documented human propensity to overattribute conduct to an individual's character and de-emphasize the circumstances that gave rise to the conduct, it is important to develop the character of a client or other legal actor whose actions might incline an audience to feel unsympathetic towards him or her.207

Character can be established directly or indirectly.208 To establish character directly, a writer can describe a character or party's

200. For the discussion of these techniques, I owe a great deal to Elizabeth Fajans \& Mary R. Falk, Untold Stories: Restoring Narrative to Pleading Practice, 15 LEGAL WRITING: J. LEGAL WRITING INST. 3 (2009).

201. Id. at 24 .

202. Id.

203. Id.

204. Id. at 25.

205. Id.

206. Id. at 30.

207. Lawrence $M$. Solan has explained the "correspondence bias" as: "[ $t]$ he propensity to overstate the role of character and to understate the circumstances in which an individual acts." Lawrence M. Solan, Intuition Versus Algorithm: The Case of Forensic Authorship Attribution, 21 J.L. \& POL'Y 551, 576 (2013); see also Lawrence M. Solan, Lawyers As Insincere (but Truthful) Actors, 36 J. LEGAL PROF. 487, 490 (2012) ("People tend to overestimate the extent to which the behavior of others stems from their personal characteristics, and to underestimate the extent to which the behavior is a normal reaction to circumstances."). With "correspondence bias" in mind, advocates may also be able to encourage audiences to view the opposing party's actions as representative of that party's character, rather than as the product of complex circumstances.

208. See Fajans \& Falk, supra note 200 , at 31. 
thoughts, appearance, body language, et cetera.209 To establish character indirectly, the writer can describe actions and words of the character or party. 210

The point of view established by the writer will determine through which character's/party's eyes the audience views the story.211 Depending on the level of "psychic distance" between the reader and the narration of the story, the writer can create greater empathy and reliability in the narrator.212

Detail is another ingredient crucial to development of a persuasive narrative.213 Specific factual detail, whether an individual detail or a multitude of elaborate detail, can have very effective persuasive power. 214

Based on this background in narrative theory and narrative tools, this Article now moves to a discussion of how narrative can solve the problems associated with the plausibility pleading standard.

\section{HOW NARRATIVE THEORY RESOLVES THE PROBLEMS OF PLAUSIBILITY PLEADING}

To scholars of law and narrative, the promise of narrative theory for understanding the plausibility standard should come as no surprise. Narrative pervades the law.215 Narrative is also highly persuasive in law.216 Indeed, our legal system depends on narrative.217 From the stories told through testimony at trial to the narrative recounting of facts in a judicial opinion, stories are everywhere in the law.218

209. Id.

210. Id.

211. Id. at $\mathbf{3 7}$.

212. See, e.g., Cathren Kohlert-Page, Come A Little Closer So I Can See You My Pretty: The Use and Limits of Fiction Techniques for Establishing an Empathetic Point of View in Appellate Briefs, 80 UMKC L. REV. 399, 404 (2011). For an example of varying degrees of "psychic distance," see JOHN GARDNER, THE ART OF FICTION, 111-24 (1991). Including details also creates a unique point of view, which can affect a reader's view of the parties or characters in the narrative. Id. at 403 ("Details can increase the closeness the reader feels with the viewpoint party or character."). Chronology also helps establish strong point of view. See Kohlert-Page, supra, at 416. Including pre-conflict facts may help the reader understand the party or character's view of the conflict, increasing empathy for that character or party. Id. at 416.

213. See Fajans \& Falk, supra note 200 , at 40.

214. Id. at 41.

215. Peter Brooks, Narrative in and of the Law, in A COMPANION TO NARRATIVE THEORY 415, 416 (James Phelan \& Peter J. Rabinowitz eds., 2005) (describing "the pervasive presence of narrative throughout the law").

216. AMSTERDAM \& BRUNER, supra note 147 , at 110.

217. Our justice system, at its core, depends on storytelling: the concept of notice and the opportunity to be heard. E.g., U.S. CONST. amend. XIV, § 1; see also Diana Lopez Jones, Stock Stories, Cultural Norms, and the Shape of Justice for Native Americans Involved in Interparental Child Custody Disputes in State Court Proceedings, 5 PHOENIX L. REV. 457, 459 (2012).

218. Brooks, supra note 215, at 416 ("Trial lawyers know that they need to tell stories, that 
However, law as a discipline is sometimes criticized for insisting that narrative has little place in its system of objective rules.219 Professor Brooks writes that law has not explicitly recognized that narrative is one of its important tools; in fact, Brooks calls narrative the "untheorized ... content" of the law.220 The "plausibility" standard, with its use of metaphors like weight, heft and a precise "line" across which complaints must be nudged, shares in law's history of attempts to be (or appear) objective.221

Although the law has long embodied the notion that questions about what happened in a particular case can be answered by some reference to "free-standing facts," the legal academy is coming to a greater recognition that the sense of what happened in a particular case depends in great part on the choice of a narrative.222 As a result, there have been calls for a greater focus on narrative in the law generallyz23 and in the complaint specifically.224 However, no article has yet considered the possibility for narrative specifically to respond to Twombly and Iqbal's call for plausibility in pleadings, and no discussion of the implications of narrative for the plausibility standard has emerged.

Despite law's frequent denial of its narrative content, narrative theory and storytelling merit particular attention from practitioners, judges and the legal academy at this time of plausibility pleading. As

the evidence they present in court must be bound together and unfolded in narrative form."); see also Paul Gewirtz, Narrative and Rhetoric in Law, in LAW'S STORIES: NARRATIVE AND RHETORIC IN LAW 2, 5 (Paul Gewirtz \& Peter Brooks eds., 1996) (arguing that "[v]irtually everyone in the legal culture," from a "trial lawyer presenting her case to a court or jury," to "a judge announcing his findings about what happened in the case," to a "law professor writing an article" is using "storytelling" to "mak[e] an argument and try[] to persuade").

219. See, e.g., Brooks, supra note 215, at 416 ("[0]ver the centuries the professionalization of law and legal education has tended to obscure the rhetorical roots of legal practice-which might now be viewed as something of a scandal in a field that wants to believe that it is rooted in irrefutable principles and that it proceeds by reason alone.").

220. Id. at 415. Brooks writes that, to the extent the law does recognize its entanglement with narrative, it "reacts to [narrative] with unease and suspicion, so that the neglect of narrative as a legal category is possibly an act of repression, an effort to keep the narrativity of the law out of sight." Id.

221. Cf. id.; Eichhorn, supra note 86, at 969 (arguing metaphors in Iqbal were an attempt to portray the decision as "simply a fair and consistent application of precedent").

222. According to Amsterdam and Bruner, the law has long embodied the notion that questions about what happened to give rise to a particular case "can be answered by examining free-standing factual data selected on grounds of their logical pertinency." AMSTERDAM \& BRUNER, supra note 147, at 111. However, as Amsterdam and Bruner explain, "increasingly we are coming to recognize that both the questions and answers in matters of 'fact' depend largely upon one's choice (considered or unconsidered) of some overall narrative as best describing what happened or how the world works." Id. at 111.

223. See, e.g., Brooks, supra note 215 , at 423 (explaining that "law ... needs a narratology" and encouraging attention to "not only how these stories are constructed and told, but also how they are listened to, received, reacted to, how they ask to be acted upon"].

224. See Fajans \& Falk, supra note 200, at 47-48. 
Professor Gewirtz has explained, "[t]he goal of storytelling in law is to persuade an official decisionmaker that one's story is true, to win the case, and thus to invoke the coercive force of the state on one's behalf." 225 As scholars, lawyers and judges attempt to understand and comply with the plausibility standard from Twombly and Iqbal, they should consider the possibilities and promise of narrative for explaining the standard and providing a method to implement it. Narrative theory's focus on the narrative transaction and the reception by the audience is particularly appropriate for this context because of the high stakes in law generally, and at the motion to dismiss phase in particular.

\section{A. A Narrative Account of Plausibility}

In all the commentary on plausibility, the idea that Twombly and Iqbal were the Court's requests for more narrative in pleadings has not been articulated, nor has that idea been fully integrated with narrative theory. Only a handful of courts and commentators have explicitly tied the idea of plausibility to storytelling. ${ }^{226}$ However, the decisions are a natural fit for the application of narrative theory and, as shown below, cases that are surviving the plausibility standard at the motion to dismiss phase utilize well-recognized narrative techniques.

Narrative theory teaches that narratives possess plausibility to the extent they are both internally coherent and externally consistent with what an audience knows to be true about the way the world works. By requesting that pleaders demonstrate, through nonconclusory factual allegations, a plausible claim for relief, the Supreme Court in Twombly and Iqbal asked litigants-in clear terms, although not explicitly - to rely to a greater degree on narrative in pleadings. If pleaders engage in storytelling to a greater degree, utilizing the kinds of narrative techniques discussed above, they will stand a better chance of putting forth a claim that reaches the threshold of plausibility.

One way to enhance plausibility through the use of narrative is to include greater factual detail. That factual precision lends plausibility is well recognized, both in the narrative theory literature 227 and the

225. Gewirtz, supra note 218 , at 5 .

226. See Swanson v. Citibank, N.A., 614 F.3d 400, 404 (7th Cir. 2010); see also Miller, Double Play, supra note 82 , at 36 (" $[\mathrm{W}] \mathrm{e}$ may be entering an age of storytelling pleading. But will the tales be happy or sad ones? The answer may lie in the eye of the beholder.").

227. See, e.g., GARDNER, supra note 212, at 57 (describing history of including detail in literature); Rideout, supra note 147 , at 64. 
legal literature.228 Indeed, the Twombly opinion has been criticized for not being explicit enough that it essentially required more factual specificity. 229

In fact, in Twombly and Iqbal, the Court was not demanding bare factual detail only. Factual detail is one narrative tool that will help create plausibility, but it is not the sole tool at lawyers' disposal. The use of sequence, character development, and point of view, along with the inclusion of factual detail, also merit careful attention.230 Narrative techniques are important to complaint drafters and judges assessing complaints because they combine to create plausibility through the embodiment of narrative rationality.

\section{B. How Narrative Theory Answers the Specific Criticisms of Plausibility Pleading}

Understanding the plausibility standard articulated in Twombly and Iqbal as requesting a new focus on narrative also helps resolve the main complaints raised by the cases and the plausibility pleading standard.

First and perhaps most importantly, narrative theory assists plaintiffs with the "Catch-22" in which they find themselves, particularly civil rights and discrimination plaintiffs. The set of narrative tools available for plaintiffs can help them make the most of the information they have to render a claim plausible. This is particularly useful when a plaintiff is filing a claim that relies on information outside her purview, either because it is in defendant's physical possession or because it involves defendant's motivation or state of mind. For instance, of the ultimate allegations in discrimination complaint, any direct allegation of the defendant's mindset or motivation, i.e., that he acted with discriminatory animus, cannot survive the first Twombly step (which requires a court to disregard conclusory legal allegations).231 Such ultimate issues invoke Wittgenstein's seventh thesis, "[w]hereof one cannot speak, thereof

228. See, e.g., Luke Meier, Why Twombly Is Good Law (but Poorly Drafted) and Iqbal Will Be Overturned, 87 IND. L.]. 709, 734 (2012) ("[T]he relationship between factual specificity and plausibility is somewhat intuitive.... A complaint drafted with factual precision and detail tends to signal that the pleader is telling an accurate story .... The more factual specificity, the more plausible is the truth of what is stated.").

229. Id. ("[T] he Twombly opinion is somewhat ambiguous as to the relationship between plausibility and factual specificity.").

230. See supra notes 207-224 and accompanying text.

231. See, e.g., Sullivan, supra note 98 , at 1642 (noting that a civil rights plaintiff "must plead not only the harm done to her but also the motivation," thanks to Twombly and Iqbal's discarding of "conclusory" legal allegations; a plaintiff cannot merely allege that the adverse employment action, for instance, was motivated by discrimination, as it would be a "formulaic recitation of the elements" of the cause of action). 
one must be silent."232 Rather than bluntly identifying a defendant's state of mind, the plaintiff must approach showing mindset or intention obliquely, through facts, as any other writer would.233 A narrative that includes rich, substantial detail, careful sequencing, and characterization can shed light on a defendant's state of mind or intention without relying on "conclusory" statements about that mindset.

Indeed, narrative theory recognizes that the way in which a story is told creates an effect in its reader that is persuasive, if done well, regardless of the truth status of the story. By creating a narrative that is internally coherent in terms of structure and externally consistent with the stock stories in our culture, the plaintiff can meet the plausibility requirement. Thus, to the extent that the Court has imposed a higher standard on pleaders through the plausibility standard, narrative helps overcome it. Whether one understands the plausibility standard as more demanding than the Conley "no-set-offacts" formulation or whether one believes the Court made no changes to civil pleading standards, a greater focus on narrative helps plaintiffs capture and harness the potential of the complaint for storytelling. ${ }^{234}$

Second, greater focus on narrative also resolves concerns about the subjectivity and ambiguity of the plausibility pleading standard. Understanding plausibility as a function of narrative gives judges and litigants greater direction about where the line of plausibility lies. As this article has explained, narrative theory understands stories as persuasive and plausible to the extent that they have certain characteristics, including structural coherence and correspondence with a culture's "common sense" social knowledge of stock stories.235 Understanding "judicial experience and common sense" not as idiosyncratic personal experiences but as appeals to the stories of our common culture also alleviates some of the worries associated with that directive.236 Understanding the term in a narrative sense means

232. Ludwig WitTGenstein, Tractatus Logico-Philosophicus $\S 7$, at 189 (C.K. Ogden ed. \& trans., 1922).

233. Cf. Bone, Plausibility Pleading Revisited, supra note 85 , at 860 . Bone suggests that the Court's reference to "formulaic recitations" might tell us "that the defect [in Iqbal's complaint] has to do with how closely the allegation tracks some standard way of expressing the legal element," but concludes that the legalistic recitation of Iqbal's claims could not be the problem because "it is not clear what other language the plaintiff could have used and still conveyed his meaning clearly." Id.

234. See, e.g., Fajans \& Falk, supra note 200, at 47-54.

235. See infra Section III.A.

236. On the subject of judicial experience, Henry S. Noyes offers a distinction based on a "careful review of the meaning of 'judicial experience' in the Supreme Court's opinions." Henry S. Noyes, The Rise of the Common Law of Federal Pleading: Iqbal, Twombly, and the Application of 
that the judge should assess plausibility not in relation to his or her own beliefs about the way the world works, but rather in a more general way that our culture understands actions to be ordered and situations to play out.

Understanding plausibility as a function of narrative holds unique promise for those plaintiffs who bring civil rights and discrimination claims. Use of narrative tools can help plaintiffs to develop a story that will demonstrate to the audience that their claim is plausible, regardless of whether the audience shares the teller's precise life experiences. A well-crafted narrative that is conscious of its own narrativity will take into account the receiving end of the narrative transaction, and successfully tap into an available stock story to increase plausibility.

The limitations that available schema or stock stories place on the tales that can be told may present a concerning implication for reliance on narrative: in its dependence on schema, narrative shows its possibilities as well as its limits. 237 The notion that one cannot understand a story without the proper underlying schema to process it is ubiquitous in narrative theory.238 This principle demonstrates the common criticisms of the directive to rely on judges' common sense and judicial experience-if judges lack experience or notions of certain things, they will be unable to see allegations related to those

Judicial Experience, 56 VILL. L. REv. 857, 859 (2012). Rather than "assum[ing] that the application of judicial experience requires a district court to make a subjective determination of the merits of the claim based on that judge's vision of reality," Noyes suggests, observers should note that "the application of judicial experience requires a district court to refer to objective information, albeit extraneous to the complaint, to inform itself of the 'truth' of the factual picture painted by the plaintiff in the complaint," including knowledge of experts and commentators and the "experience of the courts as manifest through the results of earlier cases." Id. Noyes writes that the district courts will "develop a common law of federal pleading standards that will be improved and refined over time." Id. Noyes concludes that "consideration of information beyond that alleged in the complaint, even where it calls for a purely objective determination, permits trial courts a significant amount of discretion" that is inconsistent with the adversarial system. Id. at 898. Cf. In re Text Messaging Antitrust Litig., 630 F.3d 622, 626 (7th Cir. 2010) (identifying "a federal common law doctrine of pleading in complex cases, announced in Twombly").

237. See Martha Minow, Stories in Law, in LAW'S STORIES: NARRATIVE AND RHETORIC IN LAW 24, 36 (Peter Brooks \& Paul Gewirtz eds., 1996) ("A story also invites more stories, stories that challenge the first one, or embellish it, or recast it. This, too, is a virtue to be copied.").

238. See Berger, supra note 156, at 264-65, 298. Berger explains schema as frames for understanding experience: "We make sense out of new experiences by placing them into categories and cognitive frames called schema or scripts that emerge from prior experience." Id. at 264. On a larger level, schema provide a "cultural understanding that organizes knowledge of events, people, objects, and their characteristic relationships in a single gestalt structure that is experientially meaningful as a whole." Id. at 265 (internal quotations omitted). However, once a knowledge structure involving schema exists, "judgments are more likely to be based on assumptions derived from categories and schemas than on evidence of individual characteristics" of a situation. Id. at 298. 
experiences as plausible. 239

However, in cases in which an appropriate stock story is not available, or when cultural stock stories could work against the drafter (in that they make the client's story appear implausible), the drafter can still be aware of prevailing cultural stock stories and use the techniques of narrative to avoid telling a tale making her right to relief implausible.240

Further, even where some litigants complaining of discrimination lack an existing appropriate stock story to utilize in pleadings, the justice system over time can adapt, bringing new stories into the canon of cultural stock stories; once a narrative becomes a part of a culture, it is available for would-be storytellers to utilize, mining and adapting the narrative for its applicability to the teller's own tale.241 Thus, to the extent plaintiffs continue drafting complaints that include well-crafted factual narratives, and through the recursive process of

239. In the narrative transaction, often "plausibility is in the eye of the beholder." Kassem, supra note 105, at 1447 (identifying studies showing that "whether one believes an invidious discrimination narrative offered by a member of a particular group depends in significant part on the personal background of the observer relative to that of the individual offering the discrimination narrative"); see also Christine Metteer Lorillard, Stories That Make the Law Free; Literature As A Bridge Between the Law and the Culture in Which It Must Exist, 12 TEX. WESLEYAN L. REv. 251, 256 (2005) ("[T] he choice of which story to privilege is most often determined by the story that comes closest to the experience of the listener."). To some extent, studies bear out this theory: judges' backgrounds do correlate with case outcomes in some instances. E.g., Sue Davis et al., Voting Behavior and Gender on the U.S. Court of Appeals, 77 JudiCATURE 129 (1993) (finding " $[t]$ he votes of women circuit court judges in employment discrimination and search and seizure cases differ from those of their male counterparts"); Jennifer A. Segal, The Decision Making of Clinton's Nontraditional Judicial Appointees, 80 JUDICATURE 279 (1997) (studying "decision making of President Clinton's nontraditional appointees to the federal district courts"); see also Kassem, supra note 105, at 1459 \& n.66 (reviewing recent studies regarding how "race and gender of individual judges impact judicial decision-making").

240. Sheppard, supra note 151, at 202-05 ("[W] hen a stock story that is not favorable to the client is triggered by the facts of the case, and a suitable alternative stock story is not available, a lawyer must tell a counterstory that presents the client's story from a different perspective. This new perspective must be one that will not evoke the unfavorable embedded knowledge structures triggered by the unfavorable stock story.").

241. Law and narrative has often been used as a way to bring outsider voices into the "fold" of legal academia, promising that, once shared, outsider voices and stories can be better understood by those who lack the lived experience reflected in the narratives. See, e.g., George A. Martinez, Philosophical Considerations and the Use of Narrative in Law, 30 RUTGERS L.J. 683, 684 (1999) (exploring the importance of narrative "as a way to introduce a perspective that is not represented in mainstream legal discourse").

Similarly, Sullivan has proposed using factual detail in discrimination complaints, "simply pleading this social science [research demonstrating the pervasiveness of discrimination] as a fact, thereby requiring the court to take that fact as true." Sullivan, supra note 98 , at 1663 . This method also turns the notion of judicial experience and common sense on its head, by alleging "pleading that the phenomenon of discrimination is more common than the courts might otherwise believe." Id. at 1662 . Along similar lines, Sherry suggests that one response to the heightened pleading standard is to "attack its underlying factual assumptions" using empirical work to study, among other things, the "meritoriousness of complaints that survive to the motion-to-dismiss stage," the "costs of discovery generally or for particular cases." Sherry, supra note 86 , at 184 . 
challenges through motions to dismiss and appeals, the common set of stock stories available in our culture through which we understand the world will expand, ultimately leading to better understanding of which claims are plausible. 242

Greater emphasis on narrative also helps resolve the problem of the plausibility standard's ambiguity by providing judges with a practical framework for assessing the plausibility of pleadings. By interpreting the plausibility standard with reference to narrative, lower-court judges can fill the gap between the Supreme Court's instructions in Twombly and Iqbal and the difficult task of weighing a complaint's heft to determine if it has passed the threshold from sheer possibility into plausibility.

Indeed, at least one appellate court has explained that the plausibility inquiry involves assessing pleadings for the strength of the story they tell.243 The Seventh Circuit has interpreted the plausibility inquiry as a charge to courts to evaluate pleadings based on whether they contain "enough details about the subject-matter of the case to present a story that holds together," by asking "could these things have happened, not did they happen."244 This framework obviously references narrative coherence-Is the story internally consistent such that it "holds together"? Does it contain "enough details" to be complete?-and narrative correspondence-Does the story match the audience's social understanding of what could or typically does happen?-and also provides a clear vocabulary and set of referents for district court judges concerned with explaining their reasoning to appellate courts. Judicial opinions on motions to dismiss - which provide outcomes for the parties in a particular case, guidelines for future litigants, and directions to other judges in the form of precedent-will be strengthened by a greater focus on narrative, because that focus eliminates some of the ambiguity of the plausibility standard.245

242. Such an increased focus on narrative and the sharing of outside narratives could bring into the mainstream of "judicial experience and common sense" some of the realities that, according to critics of the Twombly and lqbal decisions, would be overlooked by the new plausibility standard. See, e.g., Seiner, After Iqbal, supra note 73, at 196 (arguing that statistics on employment discrimination demonstrate that it is "an everyday occurrence in our society," and thus "much more plausible on its face that employment discrimination has occurred than that a high-level governmental conspiracy has been perpetrated or that a complex antitrust violation has been carried out"); see also Kassem, supra note 105, at 1456-57 (finding that "Muslim Americans say that discrimination and prejudice because of their Muslim identity is the biggest problem they face in the United States" and that "surveys of the general American public confirm that Muslim Americans are widely viewed with distrust and that anti-Muslim sentiment has burgeoned in the United States post-9/11").

243. See Swanson v. Citibank, N.A., 614 F.3d 400, 404 (7th Cir. 2010).

244. Id.

245. A greater focus on narrative also resolves concerns about the legitimacy of the 


\section{Narrative and Plausibility in Pleadings: Examples}

Careful analysis of cases that have survived the motion to dismiss in the post-Twombly and Iqbal world demonstrates that the use of narrative techniques does indeed help litigants overcome the plausibility standard. This section begins with a simple example of a negligence plaintiff using increased narrative to create plausibility, and then discusses four cases with more complex underlying facts and governing law. Because the criticisms of plausibility standard focus in particular on the effect that the standard can have on civil rights cases, these examples use cases involving civil rights claims, broadly construed. Two of the cases analyzed demonstrate pleadings that successfully overcame the plausibility standard. The other two cases show civil rights lawsuits that did not survive a motion to dismiss, and demonstrate that litigants ignore narrative at their peril.

The civil rights cases below were selected based on the narrative characteristics of the complaints themselves and on the analysis the plausibility question received from appellate courts. These complaints

Supreme Court's action in making substantive changes to the Federal Rules outside the rulemaking process. A greater focus on narrative does not resolve all concerns about judicial activism, but it helps to mitigate those concerns. Although greater reliance on narrative cannot excuse supplanting of the rulemaking process (as many critics allege the Supreme Court did), understanding the Court's move to plausibility in Twombly and Iqbal as seeking more narrative accounts of the facts making up a claim has normative appeal.

Proceeding from the principle that we should understand the Supreme Court to be working within the bounds of its enumerated powers rather than outside it, we can link the new appearance of the plausibility standard to the original Rule 8. See, e.g., INS v. Chadha, 462 U.S. 919, 951 (1983) ("When any Branch acts, it is presumptively exercising the power the Constitution has delegated to it."). Cf. H.L.A. HART, THE CONCEPT OF LAW 152 (1961). If we read the Court's opinions in Twombly and Iqbal as asking for a renewed attention to narrative in pleadings, then the Court is simply paraphrasing the requirement in Rule 8 that a plaintiff make a "showing"-i.e, that he or she show, not tell, in the words of the writing-class axiom-that he or she is "entitled to relief." Similarly, some of Spencer's advice is a variation on that familiar phrase, "show, don't tell." Spencer, Restrictive Procedure, supra note 111, at 193 ("In the discrimination context, a conclusory assertion might be that the defendant discriminates in hiring decisions,' rather than, 'the defendant systematically rejects Hispanic applicants with qualifications similar to those of non-Hispanic applicants that it hires.' The latter statement reports facts; the former statement substitutes a legal characterization of those facts and dispenses with factual reportage.").

Narrative also helps to deal with the criticism that plausibility will restrict access to justice. Narrative is a morally neutral tool and its use can support meritorious and non-meritorious claims. Brooks, supra note 215 , at $\mathbf{4 1 6}$ ("[N]arrative is morally a chameleon that can be used to support the worse as well as the better cause."). However, although narrative is ethically neutral, the Federal Rules of Civil Procedure embody a particular ethos: that of unrestrictive pleading and increased access to justice. A greater focus on narrative would allow plaintiffs with meritorious claims to demonstrate those merits at the pleading phase, satisfying the purposes behind the Federal Rules. Although a move towards greater detail in pleading may seem at odds with Rule 8's "short, plain statement" requirement and the simple format of the Federal Forms, it is also true that the open spirit of the Rules favors more cases decided on their merits than on procedural issues. A greater use of narrative, by increasing the number of "plausible" claims that survive the motion to dismiss phase, would further the purposes of the Federal Rules. 
are not intended as models; the cases are used here merely as samples that illustrate the potential for civil rights plaintiffs to use narrative in stating claims that are plausible under the Twombly and Iqbal standard.

\section{A Short Story: Branham v. Dolgencorp, Inc.}

Because of its straightforward subject matter and relatively simple facts, Branham v. Dolgencorp, Inc,246 a classic slip-and-fall case, is highly illustrative of narrative's power to create plausibility. The plaintiff's initial complaint was just a page long, containing only four paragraphs of factual allegations. 247 The plaintiff alleged that she was "severely and permanently injured" and "suffered pain" after falling at a Dollar General Store in Amherst County, Virginia.248 The other, equally spare allegations included that the plaintiff "fell due to the negligence of the Defendants [sic] agents and employees who negligently failed to remove the liquid from the floor and had negligently failed to place warning signs to alert and warn the Plaintiff of the wet floor." 249 The complaint, filed in state court in Virginia, was removed to the U.S. District Court for the Western District of Virginia on the basis of diversity jurisdiction.250

Not surprisingly, upon the defendants' motion to dismiss, the Western District of Virginia dismissed the complaint for failure to state a claim under the "plausibility pleading" standard of the Supreme Court's Twombly and Iqbal cases.251 The defendants argued that the factual allegations in the complaint did not raise a plausible inference that they were liable.252 The court found the plaintiff "failed to allege any facts that show how the liquid came to be on the floor, whether the Defendant knew or should have known of the presence of the liquid, or how the Plaintiff's accident occurred."253 The failure to include such factual allegations, required under Virginia law for a

246. Branham v. Dolgencorp, Inc., No. 6:09-CV-00037, 2009 WL 2604447, at *1 (W.D. Va. Aug. 24, 2009).

247. Complaint at 1, Branham v. Dolgencorp, Inc., No. 6:09-CV-00037, 2009 WL 2604447 (W.D. Va. Aug. 24, 2009).

248. Id.

249. Id. Although the complaint in Branham was short, it compares neatly with the length and level of detail contained in Form 11 of the Federal Forms, which by definition meets the pleading standards in the Federal Rules of Civil Procedure; both contain fewer than five paragraphs of factual allegations and are shorter than a page long. See FED. R. CIV. P. Form 11; see also FED. R. CIV. P. 84 ("The forms in the Appendix suffice under these rules and illustrate the simplicity and brevity that these rules contemplate.").

250. Id.

251. Branham, 2009 WL 2604447, at *1.

252. Id.

253. Id. at *2. 
negligence claim, was fatal to plaintiff's complaint.254 The court wrote that without the missing factual allegations, the complaint was merely "consistent with the possibility of the Defendant's liability," but did not plausibly establish that the defendant was negligent." 255 The court gave the plaintiff leave to amend her complaint.256

The amended complaint totaled three pages and fifteen paragraphs; the real significance in the amendments, however, was not their length, but rather the addition of significant narrativity.257 The additions to the amended complaint in Branham demonstrate the use of narrative to overcome plausibility. By comparing the initial complaint with the amended complaint, readers can easily see how detail and scene are being added to create plausibility.

First, the plaintiff added in specific factual detail; she alleged that she had gone into the Dollar General Store "to shop for clothespins" when an employee named "Jessica" told her "that she had to go to the rear of the store and turn left at the last aisle to find the clothespins." 258 The plaintiff also included detail describing her path through the store and her fall: "The Plaintiff went to the rear of the store and turned left as instructed by 'Jessica.' ... "Just as the Plaintiff turned left she stepped on water that was on the floor and directly in front of her." 259 By including these details in her amended complaint, the plaintiff developed a narrative that was more coherent (having more of the expected parts of a story, with fewer "gaps" for the audience to fill in with inference) and thus more plausible.

The amended complaint also made effective use of sequencing. In writing the amended complaint, the plaintiff chose a non-linear sequence; she did not describe the negligence as it occurred, but rather as she discovered it. Plaintiff described her fall, then alleged that she told Jessica about her fall:

11. The Plaintiff told "Jessica" that she had fallen on the water, as she turned left at the last aisle at the back of the store.

12. As "Jessica" and the Plaintiff began walking back to the front of the store "Jessica" took the Plaintiff several aisles to

254. Id. (noting that Virginia law requires a plaintiff to "establish that the defendant had actual or constructive notice of the dangerous condition on its premises and failed to remove it within a reasonable time or to warn the plaintiff of its presence").

255. Id.

256. Id. at*3.

257. Amended Complaint, Branham v. DolgenCorp, Inc., No. 6:09-CV-00037, 2009 WL 5211509 (W.D. Va. Sept. 9, 2009).

258. Id. at *1. The Amended Complaint in Branham also included more characterization, describing Jessica by name and establishing her character indirectly through her words and actions. Id.

259. Id. 
the left where a sign indicating wet floor was lying flat on the floor that sign was not visible to the Plaintiff when the plaintiff had walked several aisles over to the rear of the store for clothespins. There was no sign visible to Plaintiff to warn her of the wet floor. 260

At the end of the amended complaint, the plaintiff made allegations about how the hazard came to be in the store in the first place; she described the hazardous condition as she encountered it and then described how it had come to be, before her encounter (i.e., out of chronological order).261 This adoption of an asynchronous sequence emphasized the plaintiff's point of view and helped to create narrative correspondence, demonstrating that it was indeed plausible that plaintiff, a casual shopper, happened unaware upon a slippery floor in a store where the sole warning sign was not in the path the store employee told plaintiff to take. The details added in post-fall, including the walk with Jessica through the store to find the "sign indicating wet floor... lying flat on the floor" also demonstrated that defendant and its employees knew of the hazard.262

The defendant did not object to this amended complaint on plausibility grounds.263 Thus, Branham's relatively straightforward facts demonstrate how the addition of narrative techniques can help overcome the plausibility standard.

\section{Success Stories: Civil Rights Cases Displaying Effective Narrative Techniques}

Even in cases with more complex facts and standards, the effectiveness of narrative is clear. The following cases are particularly instructive because, in each case, a district court held that the plausibility standard was not met, and the court of appeals reversed, holding that the plaintiffs had pleaded sufficient facts to establish a plausible claim. Reviewing the disparate ways the lower and appellate courts applied the standard helps to demonstrate that plausibility requires the application of narrative techniques.

\section{a. Swanson v. Citibank, N.A.}

In Swanson v. Citibank, N.A., Gloria Swanson and Charles Routen, African-American loan applicants, sued their lender and appraiser

260. Id. at *2.

261. Id.

262. Id.

263. Subsequently, the Branham case underwent discovery and was later dismissed by stipulation of the parties. 
after their home equity loan application was denied, alleging fraud and discrimination in violation of several statutes, including the Fair Housing Act (FHA).264 Swanson and Routen alleged that Citibank discouraged them from applying for a home equity loan, and that when they did apply for a loan, Citibank used an associated home appraiser to give the home a low valuation that caused the loan to be denied.265 Swanson and Routen claimed that all these actions were taken on the basis of race. 266

Swanson and Routen's complaint made effective use of sequencing. Instead of starting with a chronological listing of events that occurred, plaintiffs began with a summary of what the case was "about": in the third paragraph of the complaint, the plaintiffs alleged that the case was not simply about the denial of their loan, but was also "about Citibank's scheme of redlining in the African American community as well as discrimination against Swanson and Routen due to their racial ethnicity."267 The plaintiffs continued on to describe "redlining" and to allege "Citibank's unethical practice of redlining in Plaintiffs' African American community." 268 The plaintiffs' use of a short summary at the beginning of the complaint effectively focused the audience's attention on the core factual allegations in the long (twenty-page) amended complaint. Describing the practice of residential redlining also created narrative correspondence by tying explicitly to the idea of residential discrimination, which served as a "stock story" in the case.

Following the summary of allegations about redlining, the plaintiffs began their history of the events relevant to the complaint long before Ms. Swanson ever entered Citibank. The plaintiffs described hearing "an announcement" on the local news "that Citibank was releasing a statement to the effect that it was going to make a concerted effort to get more of the TARP money that it had accepted ... into the hands of consumers in the form of equity loans, mortgages, credit cards and car loans." 269 Only after describing this announcement did the plaintiffs put forth allegations about their application for an equity loan. This was another effective instance of sequencing: Instead of starting with the denial of their loan, plaintiffs laid out facts that established their

264. Swanson v. Citibank, N.A., 614 F.3d 400 (7th Cir. 2010). For ease of discussion, this article will only specifically discuss Swanson and Routen's FHA statutory claims.

265. Amended Complaint at 14-18, Swanson v. Citi, 706 F. Supp. 2d 854, 859-60 (N.D. Ill. 2009), rev'd in part sub nom. Swanson v. Citibank, N.A., 614 F.3d 400 (7th Cir. 2010) (No. 09 C 2344).

266. Id.

267. Id. at 2 .

268. Id.

269. Id. at 4 . 
understanding that there might be more money available in loans to homeowners. Such details contributed to the narrative's coherence, making the story's elements more complete. The technique also helped establish the plaintiffs' point of view as consumers who believed the bank was eager to make loans.

The complaint also handled character development well, describing the words and actions of two employees of Citibank with great specificity. For instance, the plaintiffs described a branch manager who "started her conversation with Swanson by literally telling Swanson that while she... was not trying to discourage Swanson from making a loan application, Citibank's loan criteria was more stringent" than those of another bank that had turned down a previous application.270 Plaintiffs also described another bank employee who made extensive small talk about race, creating an atmosphere of defensiveness and heightened racial awareness that added plausibility to the narrative that the bank employees were making decisions based on race.271 Taken as a whole, the complaint created a dramatic picture of the kind of interaction that took place between the parties.

Upon a motion to dismiss, the Northern District of Illinois dismissed Swanson and Routen's claims, under the Twombly/Iqbal plausibility standard, because it found that they had not alleged sufficient facts to support an FHA claim.272

However, on appeal, the Seventh Circuit held that it was error to dismiss the FHA claim against Citibank because Swanson and Routen had plausibly stated a claim for racial discrimination under the FHA.273 According to the court, the complaint identified

the type of discrimination that she thinks occurred (racial), by whom (Citibank, through Skertich, the manager, and the outside appraisers it used), and when (in connection with her effort in early 2009 to obtain a home-equity loan). This is all that she needed to put in the complaint.274

The Seventh Circuit mentioned the "other, largely extraneous facts" that Swanson and Routen may have pled, such as "Citibank's announced plan to use federal money to make more loans, its refusal to follow through in her case, and Skertich's comment that he had a

270. Id. at 5-6.

271. Id. at 10.

272. Swanson v. Citi, 706 F. Supp. 2d 854, 859-60 (N.D. Ill. 2009), rev'd in part sub nom. Swanson v. Citibank, N.A., 614 F.3d 400 (7th Cir. 2010).

273. Swanson, 614 F.3d at 406-07.

274. Id. at 405 . 
mixed-race family." 275 The court concluded that Swanson had not "pleaded herself out of court by mentioning these facts." 276

From a narrative perspective, it is easy to see that those allegations likely helped develop a narrative that struck its audience as plausible, because the specific facts mentioned above established vivid characters and a richly detailed account of the interactions between Swanson and the Citibank employees; in short, those "largely extraneous facts" made the story internally and externally consistent and created narrative correspondence with the audience's understanding of how the world works.

Indeed, in her opinion for the court, Judge Wood made reference to the need for plaintiffs to put together a narrative: "As we understand [Twombly and Iqbal], the Court is saying ... that the plaintiff must give enough details about the subject-matter of the case to present a story that holds together." 277 Judge Wood further explained that the plausibility inquiry requires the court to "ask itself could these things have happened, not did they happen."278 As Judge Wood explained the plausibility standard, the Supreme Court was explicitly asking for narrative coherence-a story that holds together-and narrative correspondence-could the story have happened, does this represent an understanding about the way the world works. Significantly, following the Swanson decision, at least one commentator noted that the decision signaled a new era of storytelling in pleadings.279

\section{b. Haley v. City of Boston}

The complaint in Haley v. City of Boston also demonstrates the power of narrative to establish plausibility. The plaintiff, James Haley, had spent 34 years in prison for murder-of his sister-in-law's boyfriend.280 Haley maintained his innocence throughout his incarceration, and eventually obtained proof that exculpatory evidence in the possession of the Boston Police Department had been withheld.281 The withheld evidence included exculpatory interview statements from the only witnesses who linked Haley to the crime scene. ${ }^{282}$ Based on this evidence, Haley's conviction was vacated.283 $\mathrm{He}$

275. Id. at 405-06.

276. Id. at 406 .

277. Id. at 404 .

278. Id.

279. Miller, Double Play, supra note 82 , at 36.

280. Complaint at 1, Haley v. City of Boston, 677 F. Supp. 2d 379 (D. Mass. 2009), amended in part, C.A No. 09-10197-RGS, 2010 WL 3198900 (D. Mass. Aug. 12, 2010), aff'd in part, rev'd in part, 657 F.3d 39 (1st Cir. 2011) (No. 09-10197-RGS).

281. Haley, 657 F.3d at 45 .

282. Id. 
later sought damages against the City of Boston and two police detectives under 42 U.S.C. $\$ 1983$ for the deprivation of due process. 284

Haley's complaint effectively used a number of narrative techniques to establish plausibility. For instance, the complaint used sequencing artfully, beginning with a summary of significant details of the case in order to grab the audience's attention. Instead of beginning with the suppression of evidence or his conviction, Haley's complaint began with the stark fact of the loss of so many years of his life, the most profoundly important fact in the case: paragraph 1 of the complaint reads, "Plaintiff James A. Haley spent 34 years in prison for a murder he did not commit." 285 The early focus supported the narrative's coherence, by directing the reader to the intended interpretation of the story.

The complaint then moved to Haley's discovery of exculpatory evidence and his successful campaign to vacate his conviction, all events that happened well after the withholding of evidence that forms the legal basis for his due process claim.286 This narrative sequence focused the audience on those details: Haley was wrongfully convicted, he served many years in prison needlessly, and the State of Massachusetts agreed that his conviction should be vacated. Through this sequence, the complaint developed a structurally complete and coherent narrative of an innocent man who has suffered needlessly.

In another place, Haley's complaint used a convergent narrative structure, describing two different versions of Haley's actions on the day of the murder. First, the complaint described the facts of the case as the prosecution presented them: "According to the Commonwealth's theory of the case,... Mr. Haley supposedly struggled with and then killed [the victim]." 287 The complaint then shifted to Haley's own perspective, identifying that "[t]he alleged actions described in the preceding paragraph did not occur," and describing Haley's version of the events on the day of the murder, when he attended a party and was at work.288 The convergent narrative structure highlighted the vast difference between the prosecution's version of the case and Haley's own version, plausibly establishing the seriousness of the Commonwealth's misconduct and the significance of Haley's deprivation. The structure also gave Haley's story narrative coherence, in the sense that the story is complete; the

283. Id.

284. Id.

285. Complaint, supra note 280 , at 1 .

286. Id.

287. Id. at 4.

288. Id. 
complaint offered an account of Haley's time that was missing from the prosecution's rejected version of events.

Haley's complaint also used character development and point of view to create a narrative that convincingly established his entitlement to relief. The complaint established Haley's sympathetic point of view by compressing the distance between narrator and character, bringing the audience very close to Haley's own thoughts, such as in this allegation: "Never losing faith that the truth would prevail, Mr. Haley has continued to assert his innocence for more than three decades." 289 The complaint used Haley's voice, to very persuasive effect. Under the heading "Plaintiff's Injuries," the complaint listed a number of "basic human experience[s]" of which Haley was "wrongfully deprived" 290 :

He missed out on the ability to share holidays, births, funerals and other life events with loved ones, the opportunity to fall in love and marry and to pursue a career, and the fundamental freedom to live one's life as an autonomous human being.291

This simple language and list of details sounds much more like a man's real regret and more credibly established the impact of the alleged deprivation, than would a bare legal conclusion that Haley "suffered damage."

Through this use of narrative technique, Haley's complaint confronted the reader (and the court) with a stock script-that of the person who is wrongly accused and loses years of his life. The wrongly convicted or wrongly accused defendant is an archetypal story in our culture,292 and tying into it enhanced the plausibility of Haley's story by giving it narrative correspondence.

The district court dismissed Haley's complaint on qualified immunity grounds, noting that there were "no supporting facts to satisfy the enhanced pleading standard set out in Twombly and Iqbal." 293

The First Circuit took a more favorable view of the facts, reversing

289. Id. at 1 .

290. Id at 8 .

291. Id. at 8-9.

292. See, e.g., John Grisham, The Confession (2010); HaRPer LeE, To Kill a Mockingbird (1960); Steve Barnes, Rogue Narcotics Agent in Texas is Found Guilty in Perjury Case, N.Y. TIMES, Jan. 15, 2005, at A12 (describing mass wrongful arrests in Tulia, Texas); Susan Saulny, Convictions and Charges Voided in ' 89 Central Park Jogger Attack, N.Y. TIMES, Dec. 20, 2002, at A1 (reporting on five men freed thirteen years after wrongful rape convictions); CoNVICTION (Fox Searchlight Pictures 2010).

293. Haley v. City of Boston, 677 F. Supp. 2d 379, 387 (D. Mass. 2009), amended in part, C.A. No. 09-10197-RGS, 2010 WL 3198900 (D. Mass. Aug. 12, 2010), affd in part, rev'd in part, 657 F.3d 39 (1st Cir. 2011). 
the district court's dismissal.294 The First Circuit called the police behavior "parlous" and wrote that "Haley's complaint sketches an unattractive tableau of the detectives' conduct." 295 The court read Haley's complaint as telling the plausible story of a man who "seasonably requested production of all exculpatory and impeachment evidence" and of detectives who "purposely failed to tell either the prosecutor or defense counsel about" exculpatory and impeachment evidence.296 The narrative techniques described above helped Haley meet the plausibility standard.

\section{Unlikely Stories: Civil Rights Cases Failing to Use Effective Narrative Techniques}

In addition to reviewing cases in which pleaders met the plausibility standard, it is also instructive to look at cases in which trial and appellate courts agreed that pleaders failed to meet the plausibility standard. Such cases show real ways failing to adopt narrative techniques may make a difference to clients.

\section{a. HDC, LLC v. City of Ann Arbor}

$H D C, L L C$ v. City of Ann Arbor demonstrates that mere inclusion of voluminous factual detail, to the exclusion of other narrative techniques, will not satisfy the plausibility standard. There, a group of developers entered into an option agreement with the City of Ann Arbor to develop city-owned land.297 The developers' goal was to create housing for individuals suffering from mental and physical challenges or recovering from substance abuse.298 The city terminated the agreement after the developers failed to meet certain permit conditions.299

In a complaint spanning 26 pages and 132 paragraphs, the plaintiffs alleged that the permit conditions were impossible to meet, and that Ann Arbor had used the failure to meet the conditions as a pretense for terminating the agreement; the alleged underlying reason for the termination was that the developer was planning to build housing for individuals with disabilities, and the city had engaged in discrimination under the Fair Housing Act.300 As written, the

294. Haley, 657 F.3d at 44.

295. Id. at 46,50 .

296. Id. at 50.

297. Complaint and Jury Demand, HDC, LLC v. City of Ann Arbor, No. 09-14027, 2010 WL 2232220 (E.D. Mich. May 27, 2010), affd, 675 F.3d 608, 610 (6th Cir. 2012).

298. 675 F.3d at 610 .

299. Id.

300. Complaint and Jury Demand, supra note 297, Although the developers alleged 
complaint began prior to year 2000 and detailed extensively the back and forth between the city and developers. 301

The complaint did not, however, mention that the plaintiffs were developing supportive housing or mention the potential residents' physical and mental challenges until its third page.302 Not until the very end of the general factual allegations did the complaint mention the plaintiffs' belief the city had a desire to prevent individuals with disabilities from living at the chosen site.303 The first time discriminatory intent was even mentioned was on page 15; even then, the complaint used conclusory allegations in the place of details. 304 For instance, the complaint alleged that " $[t]$ he City arbitrarily and unlawfully thwarted Plaintiffs' efforts to develop the Property" and that " $[t]$ he actions of the City were taken with a discriminatory intent, purpose and motivation." 305

The City moved for judgment on the pleadings, and applying the plausibility standard, the Eastern District of Michigan granted the motion. 306 The court found the complaint contained only conclusory allegations of discrimination, such as alleging "discriminatory intent" without further elaboration.307 The district court also found an "obvious alternative explanation" for claimed discriminatory behavior: legitimate business reasons regarding delay on permit conditions. 308 Thus, plaintiffs' conclusory allegation of discrimination could not overcome the plausibility standard.

The Sixth Circuit affirmed, explaining that the claims of disparate treatment were implausible because plaintiffs were a sophisticated land development firm; they agreed to the demolition permit condition during the negotiation of agreement; and Ann Arbor voluntarily engaged in the development for two years, aware of the developers' proposed project and who would be housed in it.309 The court found it important that the complaint provided no facts supporting the inference that Ann Arbor sought to derail the project

disparate treatment, disparate impact, and reasonable accommodation claims, in addition to state contract claims, this discussion focuses on the federal fair housing claims, specifically the disparate treatment claims.

301. Id.at 2-13.

302. Id. at 3 .

303. Id. at 14.

304. Id. at 15-16.

305. Id. at 16 .

306. HDC, LLC v. City of Ann Arbor, 09-14027, 2010 WL 2232220 (E.D. Mich. May 27, 2010) affd, 675 F.3d 608 (6th Cir. 2012).

307. Id. at *3-5.

308. Id. at *5.

309. HDC, LLC v. City of Ann Arbor, 675 F.3d 608, 612 (6th Cir. 2012). 
because it would house individuals with disabilities. 310

A review of the complaint in $H D C$ demonstrates that narrative techniques could have improved the complaint and demonstrated the claim was plausible. First, although the complaint is lengthy and includes some detail about the negotiations between the city and the developers, the detail was not meaningful. The plaintiffs could have enhanced the narrative's coherence and made better use of less space by focusing on details central to their claim; excessive details about the business deal between plaintiffs and the city was, at best, distracting to the audience.

The complaint also could have made better use of sequencing. Beginning, as plaintiffs did, with a long history of the interactions between the parties, may have only supported the courts' notions that it was more plausible the City engaged in good faith in negotiations with plaintiffs. The plaintiffs might have been more successful if they had begun by drawing their audience's attention to the ultimate termination of the contract-along with any non-conclusory factual details.

Finally, the plaintiffs in $H D C$ could have utilized narrative correspondence, the match-up between the content of a particular story and the stock stories of a larger culture, to strengthen their complaint's plausibility. Had the complaint tapped into a "stock story" about NIMBY-ism among communities like Ann Arbor, the plaintiffs might have had more success in demonstrating the plausibility of their allegations that they were victims of intentional discrimination or suffered an improper disparate impact.

\section{b. Uppal v. Hospital Corp. of America}

The fate of the complaint in Uppal v. Hospital Corp. of America311 similarly demonstrates that failing to use narrative techniques can strip a complaint of plausibility. There, a medical doctor sued four hospitals and the parent company of three of those hospitals for race and gender discrimination.312 Uppal alleged that she was the victim of discrimination and was subjected to a hostile work environment on the basis of her gender, race and national origin.313 She also alleged that she was retaliated against for complaining to her employer regarding the unlawful discrimination and harassment.314

310. Id. at 612-14.

311. Third Amended Complaint, Uppal v. Hosp. Corp. of Am., No. 8:09-cv-634-T-33TBM, 2011 WL 2631869 (M.D. Fla. July 5, 2011), aff'd, 482 F. App'x 394 (11th Cir. 2012).

312. Id. at 2-3.

313. Id. at 2 .

314. Id. 
Uppal's complaint detailed problems at work, including being suspended, losing patient referrals, having negative letters written about her to other hospitals, and losing privileges at various hospitals due to her lack of board re-certification. 315 However, the complaint did not give any details illustrating how she was being treated differently than others similarly situated; instead, the complaint stated (in conclusory fashion) allegations such as the following: "Other similarly situated employees outside Plaintiff's protected classes who had disciplinary issues at other hospitals were not denied privileges" at one of the defendant hospitals. 316 Uppal's complaint, on the whole, suggests that she was aware of more specific factual information but failed to provide it in a narrative form.

The district court held that Dr. Uppal's complaint failed to allege with the plausibility required by Twombly and Iqbal that the hospitals treated similarly situated employees outside of her protected classes more favorably. 317 According to the court, her discrimination counts stated in a conclusory fashion that other similarly situated employees not of Uppal's gender, race and/or national origin were not treated in the same way as Uppal, but did not support these claims with any factual allegations.318 The court found it was not plausible that gender, race and/or national origin played any role whatsoever in Defendant's actions. 319 Instead, "the generic factual allegations showed workplace difficulties entirely consistent with non-gender, non-national origin and non-racebased personality disputes." 320

The Eleventh Circuit agreed, noting that Dr. Uppal's repeated allegations that "[o]ther similarly situated employees outside Plaintiff's protected classes" engaged in similar misconduct, but were not disciplined, was not factual, but rather only recited in a conclusory fashion an element of a prima facie Title VII case.321 Because she "never once supplemented these allegations of disparate treatment with any factual detail, such as even a brief description of how the alleged comparator employees were outside of her protected class," Dr. Uppal failed to meet the plausibility standard. 322

Dr. Uppal's complaint could have been improved by the application of narrative techniques, in particular, detail. Had Dr. Uppal's

315. Id. at 5-8.

316. Id. at 7.

317. Uppal v. Hosp. Corp. of Am., 8:09-CV-634-T-33TBM, 2011 WL 2631869, at *3-*4 (M.D. Fla. July 5, 2011) affd, 482 F. App'x 394 (11th Cir. 2012).

318. Id. at $* 4$.

319. $l d$.

320. Id.

321. Uppal, 482 F. App'x at 396.

322. Id. 
complaint identified with detail any individuals who were treated differently than she was, that would have made her story more plausible. More information would have given her complaint narrative coherence, because it would have contained the expected parts of the story. Absent such detail, the problem with Dr. Uppal's complaint is that it does match up to a stock story with which many lawyers, judges, and law clerks are no doubt familiar-the story of someone who has problems at work. Without more detail regarding the treatment she encountered or "how the alleged comparator employees were outside of her protected class," Dr. Uppal's narrative did not correspond to a story about discrimination.

Developing character or point of view could also have enhanced that stock story. Compared to Haley's complaint, Dr. Uppal's complaint is lacking in the detail, character development, and artfullyrendered point of view that made his claim appear more plausible. Here, more personal details would have enabled Dr. Uppal to depart from the stock story about a woman plagued with personal troubles at work and would have given the audience a plausible discrimination story.

As both Uppal and $H D C$ show, legal writers who ignore narrative theory and narrative techniques do so at their peril; the application of narrative to complaints in this world of plausibility pleading gives litigants a powerful tool.

\section{Resolving Possible Problems with an Increased Emphasis on Narrative}

While an increased reliance on narrative shows great promise for understanding and overcoming the plausibility standard, there are several challenges that this increased reliance might pose. An increased reliance on narrative may raise several key concerns, including: (a) "pleading one's self out of court"; (b) negative implications for later discovery; and (c) unethical behavior. However, such concerns should not be an impediment to the use of narrative.

Given the definition of the plausibility inquiry, and the way lower courts have applied it, "pleading one's self out of court" 323 -in other words, including additional facts so that that another interpretation of the facts, other than plaintiff's claim, appears equally or more plausible-is not likely to be a problem. Even in Twombly, the Court found the existence of an obvious alternative explanation mattered

323. See, e.g., Edwards v. Snyder, 478 F.3d 827, 830 (7th Cir. 2007) (noting that, while a plaintiff may fail to plead sufficient facts to meet a pleading standard, a "complaint can also allege too much; a plaintiff may unwittingly plead himself out of court by alleging facts that preclude recovery"). 
only insofar as it rendered the plaintiff's claim less than plausible. 324 Thus, as long as the plaintiff's claim is plausible, the existence of other alternative explanations should not matter until the plaintiff is required to prove his or her claim. The only time to be concerned with over-pleading is when the extensive facts, as pleaded, demonstrate that plaintiff cannot as a matter of law recover on his claim. 325

For example, in a recent Seventh Circuit case, a lower court concluded that a plaintiff claiming sex discrimination had "pleaded herself out of court" by including in her complaint facts that might have supported a theory of politically-based animus.326 The Seventh Circuit reversed, on the ground that, even if the plaintiff's complaint made other theories of recovery plausible as well, that did not detract from the plausibility of the plaintiff's claim.327 The court reiterated the familiar maxim that legal inconsistency in a complaint-that is, facts consistent with other claims in addition to the claim being assertedcould be tolerated, as long as the facts pleaded in the complaint made the plaintiff's claim plausible. 328

Increased reliance on narrative in complaints, including specific factual allegations in the complaint, also should not raise concerns about whether pleaders will encounter discovery problems down the road, in those cases when a pleader hopes to develop further factual knowledge through broad discovery. 329 First, Rule 26 permits a broad scope of discovery, including "any nonprivileged matter that is relevant to any party's claim or defense." 330 Concerned litigants can also tailor the degree to which their allegations will foreclose later discovery. As well, pleading with greater focus on narrative, including specific facts and details, may remind parties of the proper focus for discovery. To the extent more narrative in pleading narrows issues for discovery, the practice will have the salutary effect of decreasing litigation costs for both sides and effectuating one of the Court's goals for the plausibility pleading standard.331

324. Twombly, 550 U.S. at 567-68.

325. See, e.g., Edwards, $478 \mathrm{~F} .3 \mathrm{~d}$ at 830.

326. Tamayo v. Blagojevich, 526 F.3d 1074, 1086 (7th Cir. 2008) ("The district court concluded that Ms. Tamayo pleaded herself out of court by filling twenty-two pages of her complaint with facts showing the political motivations behind her low pay and constructive discharge.") (citing Tamayo v. Hamer, 06 C 3151, 2007 WL 1576528 (N.D. Ill. May 30, 2007) affd in part, rev'd in part and remanded sub nom. Tamayo v. Blagojevich, 526 F.3d 1074 (7th Cir. 2008)).

327. Id.

328. Id.

329. See, e.g., Fajans \& Falk, supra note 200, at 15.

330. FED. R. CIV. P. 26(b)(1).

331. See, e.g., Rebecca Love Kourlis et. al., Reinvigorating Pleadings, 87 DENV. U. L. REv. 245, 247 (2010) ("Discovery would still be available to flesh out evidence on disputed issues, albeit in 
Another potential objection to increased use of narrative in complaints is that reliance on narrative may give rise to greater temptation for litigants to engage in unethical behavior, including making false statements in complaints. 332 The fear of sanctions could be one reason that litigants have not already seized on the narrative tools this article proposes.333 However, Rule 11 sanctions have applied since long before the advent of the plausibility standard, and lawyers are familiar with the rule's requirements. 334

Greater reliance on narrative may also raise the question whether it is ethical to exploit one's knowledge of narrative persuasion to gain an advantage in litigation.335 Such a criticism-that the use of narrative could be "exploitative"-would reflect another of the law's attempts to keep its "narrativity" out of sight by defining itself as objective and rational.336 However, there is sufficient recognition that "story is ... an important element in law" 337 to rebut any argument that use of narrative to persuade is in and of itself exploitative. Moreover, the risk of indeterminacy in every story - that is, the chance that an audience, including a judge, may discern a different story than the one the teller/advocate intends-should guard against the risk of exploitation through use of narrative. 338

Finally, it should be noted that, even though increased focus on narrative has great promise for litigants and courts in resolving the plausibility standard, narrative may not receive explicit acceptance in the terms this article proposes. Law has long denied its interaction with narrative, or tried to regulate the kinds of stories that can be

a more focused manner. The pleading of material facts ... would not be designed to restrict access to the courts; to the contrary, it would increase access by making participation in civil litigation economically more feasible.").

332. See, e.g., Fajans \& Falk, supra note 200, at 41 ("Facts that have the ring of truth but which cannot be verified, or even investigated, should likewise be omitted, for fear of invoking Rule 11 or its state analogues.").

333. Sullivan, supra note 98 , at 1675 (noting that although a highly-detailed approach might allow a plaintiff to claim any fact to avoid dismissal, such allegations would be constrained by Rule 11's limitations on the factual investigation necessary); Yin, supra note 86, at 212 (noting that "sanctions could be a reason" why litigants do not craft more elaborate factual allegations).

334. See, e.g., Fed. R. Civ. P. 11. ("By presenting to the court a pleading ... an attorney... certifies that to the best of the person's knowledge ... the factual contentions have evidentiary support or... will likely have evidentiary support after a reasonable opportunity for further investigation....").

335. See, e.g., Brian Foley, Applied Legal Storytelling, Politics, and Factual Realism, 14 LEGAL WRITING: J. LEGAL WRITING INST. 17, 47 (2008) (noting the possibility that stories tend "to facilitate abuse by advocates because of stories' possible appeal to emotion over intellect").

336. See, e.g., Brooks, supra note 215, at 415.

337. Richard A. Posner, Legal Narratology, 64 U. CHI. L. REv. 737, 740 (1997); see also infra notes 215-25.

338. See Foley, supra note 335 , at 47 (arguing that, in order to let "the audience construct and experience the meaning of the story for itself ... the storyteller must give up some control over that meaning-making, lest the storyteller turn the story into a mere rhetorical argument"). 
told, in order to maintain its objectivity and disciplinarity. ${ }^{339}$ However, even without explicit recognition in a court opinion, litigants can be aware of the possibilities of narrative to establish plausibility and judges can look for narrative in complaints.

\section{CONCLUSION}

The "plausibility" standard set out in Twombly and Iqbal has been criticized for its departure from the spirit of the Federal Rules, its arbitrariness, and its deleterious effects on the administration of justice. Nonetheless, it is the law of the land, and lower court judges and litigants must learn to adapt to its requirements. Narrative theory can help both judges and litigants adjust to the plausibility standard. Indeed, a review of court opinions reveals that lower courts are taking the Supreme Court's plausibility standard seriously and are evaluating pleadings based, in large part, on the strength of the stories those pleadings tell.

Litigants can help move their claims across the line of plausibility by making better use of narrative techniques. Narrative techniques may be especially useful to a plaintiff who asserts a claim of illegal discrimination or another civil rights violation, as it is in these contexts that a judge's "judicial experience and common sense" may diverge most significantly from the litigant's allegations. In such instances, a litigant should consider the ways audience members (who may or may not share the same cultural background and stock stories) will "read" her allegations and should consider utilizing additional narrative techniques to demonstrate a claim's plausibility.

Similarly, judges should pay attention to narrative theory and open themselves to a consciousness of the ways a narrative works upon a reader. When employing "judicial experience and common sense," a judge must also be aware of the possibility of other stories that could be told besides the stock stories most familiar to the judge, and be careful to neutrally assess the plausibility of a plaintiff's claim.

Through greater awareness of narrative theory and greater use of narrative techniques, the story of plausibility pleading-which is still being told-may yet have a happy ending.

339. See, e.g., Peter Brooks, Narrative Transactions-Does the Law Need a Narratology?, 18 YALE J.L. \& HUMAN. 1, 2 (2006) (noting that one can "search in vain for any explicit recognition by legal decision-makers that how a story is told can make a difference in legal outcomes"). See also id. at 9 ("While justices can be sensitive readers of narrative accounts, there is virtually no recognition in Court opinions that there may be a general problem of narrative, that is, with the forms of telling in which issues are presented."). 
